Portland State University

PDXScholar

Spring 6-28-2013

\title{
The First Year: Development of Preservice Teacher Beliefs About Teaching and Learning During Year One of an MA TESOL Program
}

Emily Spady Addiego

Portland State University

Follow this and additional works at: https://pdxscholar.library.pdx.edu/open_access_etds

Part of the Bilingual, Multilingual, and Multicultural Education Commons, and the Other Teacher Education and Professional Development Commons

Let us know how access to this document benefits you.

\section{Recommended Citation}

Addiego, Emily Spady, "The First Year: Development of Preservice Teacher Beliefs About Teaching and Learning During Year One of an MA TESOL Program" (2013). Dissertations and Theses. Paper 985. https://doi.org/10.15760/etd.985

This Thesis is brought to you for free and open access. It has been accepted for inclusion in Dissertations and Theses by an authorized administrator of PDXScholar. Please contact us if we can make this document more accessible: pdxscholar@pdx.edu. 
The First Year: Development of Preservice Teacher Beliefs About Teaching and Learning During Year One of an MA TESOL Program

by

Emily Spady Addie go

A thesis submitted in partial fulfillment of the requirements for the degree of

\author{
Master of Arts \\ in \\ Teaching English to Speakers of Other Languages
}

Thesis Committee:

Susan Conrad, Chair

Keith Walters

Kellie Gallagher

Portland State University

2013 


\begin{abstract}
This qualitative, longitudinal study followed four first-year MA TESOL students through the ir initial year in a teacher training program with the goal of determining whether their overall be liefs about teaching and learning changed over time as a result of program curriculum and other outside factors. An analys is of semi-structured interviews with each participant, conducted one to two times per quarter, revea led that participants' beliefs appeared to evolve as a result of coursework and teaching practice. Partic ipants' identities as teachers also showed signs of evolution and development. The participants attributed the majority of their development to hands-on teaching practice, though there was evidence that they began to integrate more the oretical aspects of program curriculum by the end of the year. However, the participants also demonstrated a lack of interest in theoretical and research-related coursework that pers isted throughout the ir first year. Participants' lack of interest and stress brought on by unfamiliar material may have limited the amount of integration of research and theory into their practice. Findings suggest a mismatch between program goals and student goals, with students being focused on teaching practice and the program being focused on both the practical and theoretical aspects of the curriculum.
\end{abstract}




\section{ACKNOWLEDGMENTS}

I would first and foremost like to thank my advisor, Susan Conrad, for all of her help during the two years that I spent researching and writing this thesis. Without her feedback and encourage ment, I would not have found the motivation to see this document reach its full potential. Thank you, Susan, for taking a chance and agreeing to be my advisor before you knew me as a student! Also, thank you so much to my other two committee members, Keith Walters and Kellie Gallagher, for making time to read and review this thesis. Your help and input have meant a lot to me.

I would also like to thank my participants for taking the time to meet with me even when the ir schedules made it difficult. The ir willingness to participate in this study was incredibly generous and I am extremely grateful to them for all the hours of data they gave me.

I am likewise grateful to the members of the department who agreed to meet with me to talk about program curriculum. The ir interviews gave me helpful insight into the program which greatly helped my writing process. Thank you all for your time and for valuable input.

Finally, thank you to my friends, boyfriend, and family who supported and put up with me through this process. I would not be graduating without your love and encouragement. 


\section{TABLE OF CONTENTS}

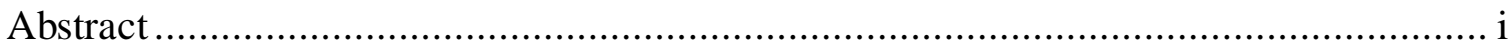

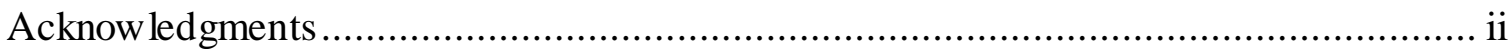

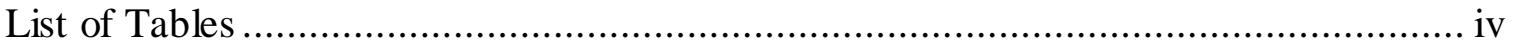

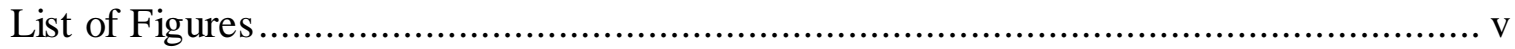

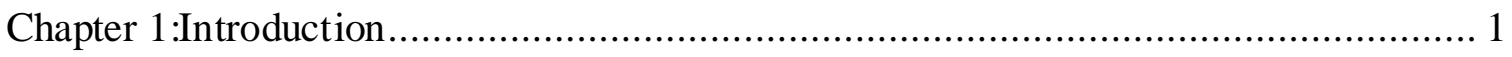

Chapter 2: Review of the Literature

2.1: The Nature of Preservice Teacher Beliefs.................................................. 4

2.2: How Preservice Teachers Construct Know ledge ......................................... 8

2.3: Recent Studies in Preservice Teacher Training ..........................................10

2.4: Summary and Research Questions .........................................................13

Chapter 3: Methodology

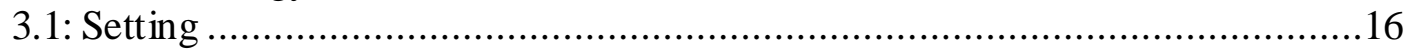

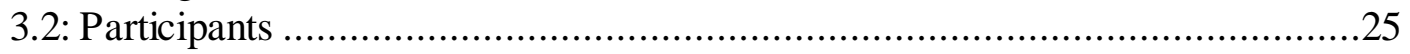

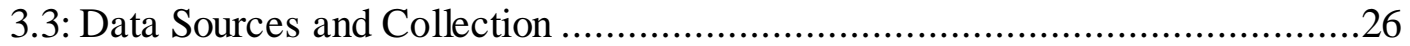

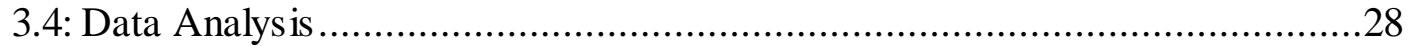

3.5: Researcher Role and Reliability ................................................................

Chapter 4: Results and Discussion

4.1: Results

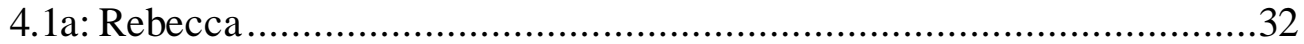

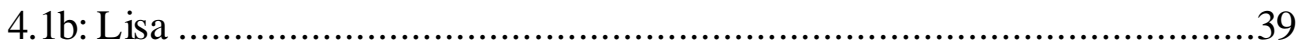

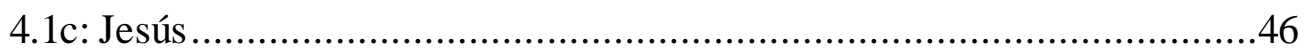

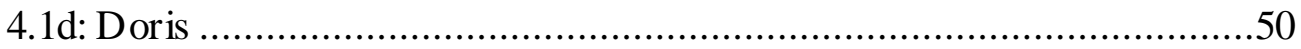

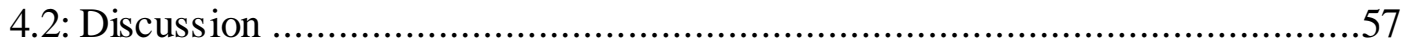

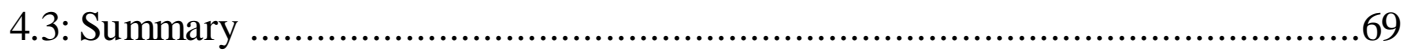

Chapter 5: Implications and Conclusion

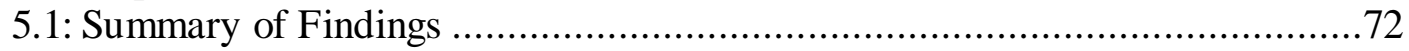

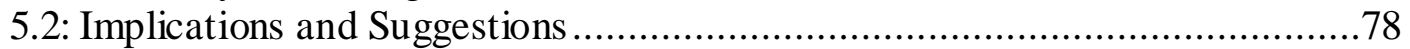

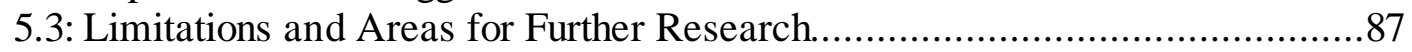

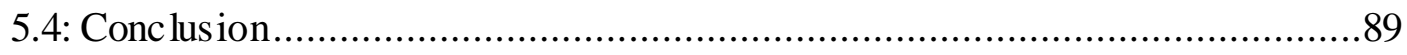

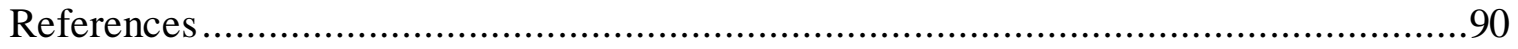

Appendices

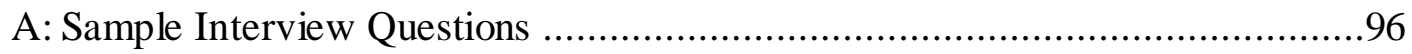

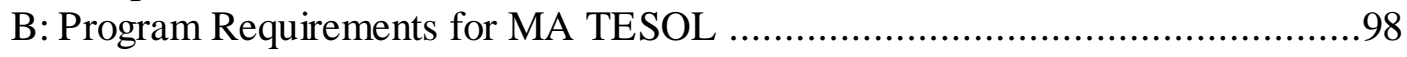

B: Program Requirements for Teaching Portfolio ..............................................100 


\section{LIST OF TABLES}

Table 1: Overview of Program Curric ulum............................................................19 


\section{LIST OF FIGURES}

Figure 1: Makeup of Program Curric ulum ........................................................18

Figure 2: Program View of Curriculum vs. Student View ....................................73 


\section{CHAPTER 1: INTRODUCTION}

In 2010, only one year after getting my Bachelor's Degree, I entered the MA TESOL program of Portland State University's Department of Applied Linguistics. I had no teaching experience; I had taken only one linguistics class as an undergraduate-I was in over my head. The first term was a whirlwind of new, confus ing information and concepts I did not understand, and I often found myself panicked, miserable, trying frantically to figure out how one thing related to another before I was tested on it. I felt like I was juggling bricks without ever having learned to juggle.

During the second and third terms, however, things began to fall into place. I started to make connections. I wrote and researched. I tutored, observed classes, and taught adult community ESL. I ended my first year miles away from the terrified novice that I had been. My beliefs about teaching and what it meant to be a teacher had changed, shifted, and grown. And as I was changing, I observed many interesting-sometimes parallel, sometimes not — changes in my peers. I also began to wonder what the collective experience of our cohort had been during that first year. I began to wonder if another group of graduate students would have a similar experience, if there was a pattern.

Currently, many universities in the US and Canada offer MA TESOL programs or the equivalent. The TESOL webs ite (2006) lists 160 master's degree programs in the United States, not counting those that are conducted online or provide only a certificate. Despite this wealth of MA TESOL programs, little research has been done on the 
experience that graduate students undergo while enrolled in these programs. Of the research that has been done, almost all has been done by instructors in the program, not by students. Many of the studies have focused on students' experience in practica (Pray \& Marx, 2011; Rymes, 2002), not in the program as a whole. Of the studies that have addressed students' practical experience and their reaction to program content, few have focused specifically on how students' be liefs about teaching changed as a result of these two factors (Ethell \& McMeniman, 2000). Generally, the studies I found on TESOL students' experience focused either on the ir reaction to program curriculum or the ir personal evolution as teachers (e.g. Lin, 2000; Urmston \& Pennington, 2008), not both. Few recent studies have examined preservice teachers' personal and professional development as a result of program curriculum.

Because I completed my first year in the program feeling like program curriculum had a direct effect on my own development as a teacher, I was surprised to find that the studies I surveyed linked curriculum and personal development—specifically, development of beliefs about teaching and learning_obliquely if at all. These studies also failed to address the effect that factors outside of program curriculum (e.g. stress, interactions with classmates) had on students' development. Furthermore, I found that none of the studies I surveyed were conducted on students in a program whose curriculum combined linguistics, pedagogical theory, and applied research. The program I chose to study was unique in this aspect. 
My goal in designing this study was to discover whether a link exists between program curriculum and the development of preservice teacher (PST) beliefs. I also wished to examine the effect that outside factors have on development of beliefs. The context in which I conducted this study was unique: I was a student as opposed to an instructor and I studied a program which combines linguistics, research, and pedagogy. It was my hope that this study would offer a new perspective on the experience of students in MA TESOL programs and contribute new and valuable information to the existing literature.

The study cons ists of five chapters. In the second chapter, I discuss the existing literature on my topic, state my research questions, and explain how my research questions target information not addressed by previous studies. In the third chapter, I describe the background of my study and the methods I used for data collection and analys is. In the fourth chapter I present my results. In the fifth chapter, I conclude with a discussion of my results and their implications for the program, previous studies, and future areas for research. 


\section{CHAPTER 2: REVIEW OF THE LITERATURE}

\section{INTRODUCTION}

In this chapter, I review early literature about PST and novice teacher beliefs. I then discuss seminal studies and theories about how teachers build know ledge, whether internally or as part of a socially-situated context. I go on to review more recent studies about PSTs in TESOL programs, focusing on some of the common trends that emerged. Finally, I use the information gained from the studies I reviewed to formulate my research questions.

\section{THE NATURE OF PRESERVICE TEACHER BELIEFS}

Studies of teacher and PST beliefs in the 1980's and 90's found that PSTs entered teacher education programs with pre-established beliefs about teachers and teaching (Bunting, 1984; Hollingsworth, 1989; Kagan, 1992; Lasley, 1980; Pajares, 1991;

Weinstein, 1990). The majority of these studies focused on teachers of mixed subjects and mixed levels (K-12). Early studies of teacher beliefs were characterized by large survey samples. These studies measured belief along a spectrum which was on one end authoritarian and disciplinarian and on the other end affective and nurturing.

Researchers found that most subjects fell on either one or the other side of the spectrum. Some subjects held a simplistic/authoritarian view of teaching which Jacobs (1968) called "impersonal, informal, and rigid" (p. 414). Within this system of belief, 
teachers were conceived of as distributors of information, classroom bosses and disciplinarians. Students were responsible for their own learning; the instructors provided the direction, but the students had to make use of it. Ideal characteristics for a teacher to have were authority, organization, and knowledge of the topic. This point of view was described by Hollingsworth (1989, p. 170) as "teachers teach, learners learn."

The second theme researchers found in PST beliefs was the affective/emotional view of teaching. Subjects who held this view saw teaching as a nurturing, supportive act (Bontempo \& Digman, 1985; Frusher \& Newton, 1987; Kagan, 1992; Lasley, 1980; Weinstein, 1990). Motivating factors in choosing teaching as a profession included love of children, belief in teaching as an important social institution, and a desire to help people. This system of belief conceived of the teacher's role as a helper, a facilitator of learning, and a source of support and guidance for students. Learning was viewed as a collaborative act between teacher and student. Ideal characteristics for a teacher to have were friendliness and understanding. The nurturing view of teaching involved far more affective aspects than the authoritarian view of teaching, but involved far less consideration of concrete skills and abilities needed by the teacher.

In addition to pre-established beliefs about teaching, studies in the 80's and 90's found that PSTs entered teacher education programs with what Weinstein (1990) called "unrealistic optimism" (p. 53) about the program and great confidence in their abilities as a teacher (Kagan, 1992; Pajares, 1991). PSTs reported that they had previous knowledge of teaching from having been a student most of their lives. "The classrooms of colleges of 
education, and the people and practices in them, differ little from classrooms and people [PSTs] have known for years. Thus, the reality of the ir everyday lives may continue largely unaffected by higher education, as may their beliefs" (Pajares, p. 323). Because PSTs perceived themselves already as experts in the field of education, they were optimistic about their chances and confident in their abilities. They were also less liable to perceive themselves as needing to improve or develop as teachers; thus, the teacher education programs they enrolled in did not have a great influence on their be liefs and practices.

The studies also found that beliefs were not only pre-established, but resistant to change (Calderhead \& Robson, 1991, cited in Kagan, 1992; Hollingsworth, 1989; Lasley, 1980). This was due in part to the emotional, epis odic nature of beliefs (Nespor, 1987; Pajares, 1991). PSTs linked their beliefs about teaching to experiences they had had as students, defining teacher characteristics as desirable or undesirable depending on what they had experienced. Nespor mentioned the case of a teacher who believed lessons should be "fun" and "friendly," in contrast to the lessons she remembered from her childhood (p. 320). Bontempo and Digman (1985) found that many PSTs cited past inspirational experiences with teachers as motivation for entering the field. One subject remarked, "When I was in school my teachers gave me many opportunities to improve myself. I want to give my students the same opportunities," (Bontempo \& Digman, 1985, p. 12). Because many PSTs' beliefs had both an emotional basis and a concrete basis in 
remembered experience, they tended to persist even after the PSTs had completed their education programs.

Added to the emotional impact of past experience was the emotional impact of self-perception as a teacher. PSTs tended to link their beliefs about the role of the teacher to their identity as a teacher or future teacher (Kagan, 1992; Weinstein, 1990). Weinstein found that PSTs who saw positive teacher traits as traits that they themselves possessed were more likely to feel optimistic and confident about teaching. For these PSTs, challenging one's beliefs about what constituted a good teacher meant challenging one's own efficacy or quality as a teacher. Many PSTs expressed a preference for professors whose beliefs mirrored their own, and those who did not have strong beliefs about teaching tende d to model their professors' beliefs and actions while not experiencing any actual change (Hollingsworth, 1989). Teacher education programs were therefore found to be largely ineffective in changing PST beliefs.

The majority of the studies done on PST beliefs in the 1980's and 90's shared Nespor's (1987) view of belief as emotional, episodic, and linked to past experience. Because beliefs were neither logical nor objective, they were difficult to challenge.

However, these studies did not address how teachers' know ledge and skills came into play in the ir practice and in the formation of their beliefs. The next section looks at theories on how teachers learn to teach with the goal of differentiating between belief about teaching and actual knowledge of how to teach. 


\section{HOW PRESERVICE TEACHERS CONSTRUCT KNOWLEDGE}

Literature on teacher learning is dominated by tw o schools of thought. The first posits that knowledge is socially-situated: teachers learn through interaction. The second posits that knowledge is formed internally: teachers learn through reflection.

The socially-situated view of learning is comprehensively reviewed by Liston and Zeichner (1991), who discuss pioneers such as Buchmann, They describe Buchmann's view as conceiving of learning as being socially and culturally situated. Teacher knowledge depends upon the "folkways" of teaching (Buchmann, 1987b, cited in Liston \& Zeichner, 1991, p. 63): the collective, cultural traditions of teaching and learning. Teacher know ledge and beliefs are founded in cultural cues and accumulated societal knowledge. The situation in which a person learns and the activity through which a person learns become integrated into the person's knowledge. As Pajares (1992) stated, PSTs are insiders in the field of education even before they begin their training as teachers. According to Buchmann, the fact they have spent their lives in an education context means that they have spent the ir lives accumulating knowledge about teaching.

The socially-situated view of teacher learning links beliefs and knowledge as both happening as a result of experience, though knowledge appears to be based less on individual, emotionally significant me mories than on collective, cultural memories. Another perspective on situated learning describes it as dependent not only on collective cultural experience but also on social and physical features of the learning environment. "[A] uthentic activities" (Putman \& Borko, 2002, p. 4), e.g. fieldwork, observation, and practica, are essential for the development of know ledge. Learning does 
not happen within the individual: it is distributed among "the individual, other persons, and various artifacts such as physical and symbolic tools" (Putman \& Borko, p. 5). In this view, learning cannot happen without a social context complete with other people, authentic activities, and authentic tools.

Alternatively, the reflective model of learning conceives of learning as internal and individual (Clandinin \& Connelly, 1988; 1992). Teacher knowledge is dependent upon teachers' personal experience and narratives of experience. A teacher's practical knowledge is based on a significant personal "image," "something within our experience, embodied within us as persons and expressed and enacted in our practices and actions" (Clandinin \& Connelly, 1988, p. 60). Teachers gain knowledge though reflecting on significant past experiences. The idea of reflexivity (Moore, 2004) is central to reflective learning. Reflexivity is the practice of reflecting on one's own beliefs, assumptions, experiences, and cultural background, with the goal of personal growth and deeper understanding of oneself and one's concept of the world. When applied to teachers, and ESL teachers in particular, reflexivity facilitates learning by prompting teachers to examine the ir own beliefs and self-image, and, through examination, to recognize areas for growth.

The reflective view of learning, like the socially-situated view, links knowledge closely to belief. Knowledge is also formed through significant experiences; however, unlike the formation of beliefs, which are based on emotion and are therefore difficult to challenge, the formation of knowledge occurs through careful, internal examination of past experiences. Knowledge, from a reflective standpoint, could be said to grow out of 
the same experiences that formed beliefs, but to grow more objectively and in a way more applicable to actual teaching practice.

Recent studies of preservice and novice ESL teachers have focused on how specific curriculum challenges students to formulate new know ledge and reshape the ir beliefs about teaching. In the following section, I will discuss recent studies and some of the trends many of them share.

\section{RECENT TRENDS IN PRESERVICE ESL TEACHER TRAINING}

A number of recent studies on ESL PSTs have described the transformative experience that PSTs go through in a given teacher education program (e.g. East, 2011; Lin, 2011; Osterling \& Webb, 2009; Rymes, 2002). These studies focused on the personal experiences of a small group of PSTs in either an MA TESOL program or a course within an MA TESOL or similar MA Ed. Program. Most of these studies found a distinct pattern of development, characterized by Rymes (2002) as a narrative of “personal transformation” (p. 440). Students reported initial self-doubt, fear, and lack of confidence. Some students had difficulties with the curriculum, either dis liking it or feeling confused by it (East, 2011; Osterling \& Webb, 2009). Others were overwhelmed by the demands of the program or course, especially in cases where they were required to go outside of the ir comfort zone (Pappamihiel, 2007; Rymes, 2002). At the end of the experience, be it program or course, most students reported more confidence and a greater sense of autonomy as a teacher. Students became more aware of their own limitations, pedagogical values, and predilections. They began to refine their view of themselves as teachers (East, 2011; Lin, 2011; O’Brien, 2004). 
Many of these personal transformative narratives took place during studies of practica (e.g. East, 2011; Rymes, 2002; Winer, 1992). PSTs reported that the y learned how to teach by doing it and that experience in the classroom helped them gain confidence while developing practical skills that would be useful in future teaching contexts. PSTs used the experience of teaching to add to their "tool kits" (O'Brien, p. 189), sets of activities and strategies for teaching. The hands-on experience of practica was a major factor, according to these studies, in the development of confidence and pedagogical skills.

Recent studies have also focused on reflective curricula. The programs and courses in the research used tools such as journals to prompt reflection in PSTs. Students were asked to write about their experiences in the program and about how the ir attitudes changed over time. O'Brien (2011) used a reflective teaching tool that prompted PSTs to construct metaphors about themselves and their experience as teachers-in-training. The studies of reflective curricula found that reflection helped students pinpoint and challenge their beliefs about teaching, teachers, learners, and the field of ESL. Students were able to synthesize their experience as MA TESOL students with the ir identities as teachers, building on the ir self-concept and on their concept of what they believed was desirable in a teacher (Lin, 2011; Osterling \& Webb, 2009). Some programs focused specifically on the deve lopment of awareness about L2 learner needs and intercultural sensitivity, sending stude nts into challenging multicultural contexts and asking them to reflect on their experiences (Pappamihie1, 2007; Pray \& Marx, 2010). Students reported increased 
awareness of what it was to be an L2 learner and were able to brainstorm ways in which they would apply this knowledge to their own teaching.

Some recent studies have also discussed conflicts present in preservice and novice teacher education narratives. A major conflict present in several studies is the relationship between practice and theory in PSTs' know ledge and beliefs about teaching (Ethell \& McMeniman, 2000; Fleming, et al., 2011; Peter, et al., 2012; Urmston \& Pennington, 2008). Though most of the studies I reviewed dealt with curriculum that included a practical component, these studies focused specifically on how the theoretical aspects of teacher training courses came into play in the PSTs' actual practice.

A consistent pattern in these studies was that preservice and novice teachers valued practical experience over theoretical background in their development as teachers (Ethell \& McMeniman, 2000; McCray, 2006). These studies defined "theory" as either pedagogical training or coursework in Applied Linguistics areas such as Second Language Acquisition or Sociolinguistics. Subjects reported having difficulty connecting theories learned in class to actual teaching practice: "[T] hey perceive that much of the formal on-campus course work appears irre levant when viewed from the perspective of classroom practice" (Ethell \& McMeniman, 2000, p. 87). Training programs that made the connection between theory and practice more transparent, whether through reflective coursework or interviews with practicing instructors, had more success in integrating theory into students' concept of teaching (Fleming, et al., 2011; Peter, et al., 2012). However, most students surveyed after having experienced practica and theory-based 
coursework consiste ntly reported that teaching experience had been more instrumental in altering their be liefs and building their know ledge.

By and large, the recent studies I surveyed focused on practical experience and reflective curricula as major contributors to change in PST belief and knowledge. However, a divide also emerged between theoretical coursework and practical experience. This study aims to examine how all three of these major trends, practical experience, reflexivity, and theory come into play in the development of PST beliefs.

\section{SUMMARY}

Research on PST beliefs has found that PSTs enter programs with pre-established beliefs. These beliefs can be changed or challenged by program curriculum, practical experience, or a combination of the two.

Of the early studies done on PST beliefs, none are specific to the ESL field, and few of them deal with how PST beliefs change over time as a result of curriculum and other factors. Recent research on PSTs in TESOL programs has focused on narratives of personal transformation, the use of reflective curricula, and the relationship between theory and practice. However, few of these studies have focused on a curriculum that contains not only theory but research in Applied Linguistics. The curriculum I examined is unique in that it has all the components of the curricula discussed in the studies I surveyed (theory, practice, and reflexivity) while adding a research component.

The literature on teacher learning suggests that teachers gain knowledge through a combination of socially-situated and internal, reflective practice, yet few studies have examined how the social context of PST training and the reflective elements of curricula 
combine to affect PST beliefs. In this study, I intend to examine both PST experiences from a reflective and a socially-situated conte xt. My intention is to target the internal, affective experience of being a PST as well as the cultural experience of being a student in this particular program.

In order to expand on previous research and address change in teacher beliefs specifically, while taking into account both the socially-situated and reflective models of learning, this study plans to follow a group of four MA TESOL students through their first year in a specific MA TESOL program. The research will address students' experience of the program as a whole, i.e., students' reactions to course content as well as to the structure of the program, the sequencing of classes, and the combination of different disciplines present in the curriculum. The research will also attempt to determine what the students' beliefs about teaching are at the beginning and end of the ir first year, and if any changes have occurred in the content of their beliefs. In addition to this, the research will address the effect of additional elements, e.g. teaching experience, student interaction, and elective classes, on MA TESOL students' experience and beliefs about teaching.

\section{RESEARCH QUESTIONS}

The research questions are as follows:

1. What change, if any, do PSTs report in their beliefs about teaching throughout the course of the ir first year in the program? 
2. How do PSTs relate their changes in belief to the program curriculum (course content, course sequencing, course structure, etc.)? To what extent do they also re late their changes in belief to factors outside of the required curriculum (affective factors, additional teaching experience, interactions with classmates, etc.)? 


\section{CHAPTER 3: METHODOLOGY}

\section{INTRODUCTION}

The following chapter provides a description of the setting in which my study took place, my participants, and my methods of data collection and analysis. I also discuss my role and trustworthiness as a researcher and some of the problems I encountered combating researcher bias and analyzing my data.

\section{SETTING}

Overview

This qualitative, exploratory study was conducted at an urban university in the Pacific Northwestern United States. The university operates on a quarter system with optional enrollment in summer term. The MA TESOL program at this university is housed in the university's Department of Applied Linguistics, which also offers a bachelor's degree in Applied Linguistics and a TESOL certificate. The program graduates about 30 students a year. It is designed as a 2-year program, though some students e lect to spend longer finishing the ir degree.

Students in the MA TESOL program are generally between the ages of 25 and 45. Most do not enter the program directly after completing the ir bachelor's degree. The majority (roughly 75 percent) of students are female. The program also admits international students, though the majority of students are native English speakers from 
the United States. Most students do not come from a background in Applied Linguistics or other social sciences. Many of them have some teaching or tutoring experience upon entering the program, though not necessarily in ESL. Some students have taught or tutored for years before beginning the program, while some have little or no teaching experience.

The program faculty comprises 9 tenure-related faculty, 8 of whom teach in the program (the 9th is a full-time researcher). Of these 8, 4 are full professors, 3 associate professors, and 1 is an assistant professor. There are also 2 adjuncts, both PhDs in linguistics, one a graduate of the department's MA program, and 1 fixed-term faculty member who is also a graduate of the MA program. Tenure-related and fixed-term faculty in the program all have international experience and experience teaching English and/or another language as a second or fore ign language.

\section{Curriculum}

The MA TESOL curriculum is composed of three main components (K. Walters, Interview, January 29, 2013): pedagogy, linguistics, and research. Pedagogy consists of knowledge about teaching, practice teaching, and the ability to reflect on teaching practice and improve as a result of reflection. Linguistics cons ists of knowledge about language acquisition and the English language with an emphasis on learning how to analyze learner language. Research consists of critically reading scholarly research in the Applied Linguistics and TESOL fields as well as conducting and writing up empirical research. 
The program is designed to develop students' abilities in the three core areas. The focus is not only on training students to teach, but also on giving them the skills and concepts they need in order to evolve independently as teachers. Reflective practice is a core component of program curriculum, as is the ability to discern how linguistic disciplines influence and inform the practice of teaching ESL. The department views know ledge of pedagogy, linguistics, and research as interrelated and vital to becoming a TESOL professional, whether this professionalism denotes teaching, conducting and publishing research, administration, or any other profession in the TESOL field. Figure 1 represents the makeup of the curric ulum.

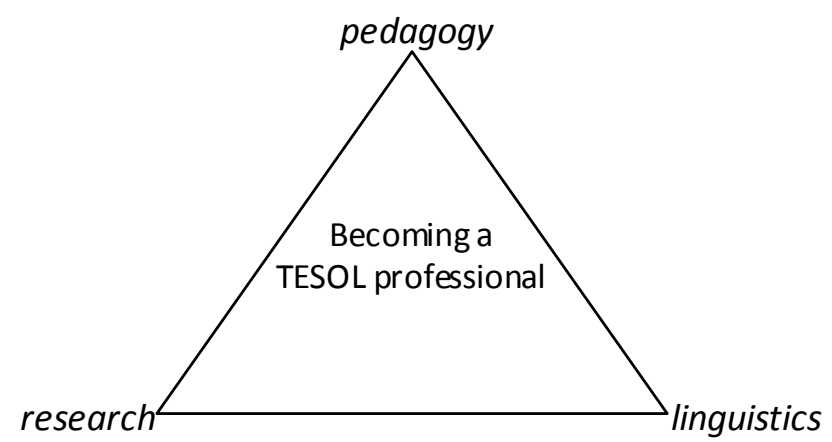

Figure 1: Makeup of program curriculum

Students in the program take seven required classes which are divided between two subject areas (for a total of 22 credits). They must also take 20 credits of elective courses in several subject areas offered by the department in order to fulfill distribution requirements. Required and elective credits are broken up into categories as shown in Table 1. 


\begin{tabular}{|c|c|}
\hline \multicolumn{2}{|c|}{ Group I: Language Education/Applied Linguistics Theory (20 credits) } \\
\hline 16 required credits: & $\begin{array}{l}\text { LING 538: Second Language Acquisition } \\
\text { LING 571: Understanding the International Experience } \\
\text { LING 577: TESOL Methods I } \\
\text { LING 578: TESOL Methods II }\end{array}$ \\
\hline Choose 4 credits: & $\begin{array}{l}\text { LING 509: Practiaum } \\
\text { LING 539: Language Assessment } \\
\text { LING 565: Administration of ESL/EFL Programs } \\
\text { LING 570: Grammar for TESOL } \\
\text { LING 575: Curriculum Design and Materials Development } \\
\text { LING 576: Corpus Linguistics in Language Teaching } \\
\text { LING 510: Special Topics (on approval) }\end{array}$ \\
\hline \multicolumn{2}{|c|}{ Group II: Foundations in Language and Linguistic Theory ( 8 credits) } \\
\hline $\begin{array}{l}\text { Linguistic Analysis: } \\
\text { Choose } 4 \text { credits }\end{array}$ & $\begin{array}{l}\text { LING 513: Linguistic Semantics } \\
\text { LING 514: Linguistic Pragmatics } \\
\text { LING 515: Linguistic Phonetics } \\
\text { LING 516: Discourse Analysis } \\
\text { LING 520: Historical-Comparative Linguistics }\end{array}$ \\
\hline $\begin{array}{l}\text { Linguistic Argumentation: } \\
\text { Choose } 4 \text { credits }\end{array}$ & $\begin{array}{l}\text { LING 511: Syntax } \\
\text { LING 512: Phonology }\end{array}$ \\
\hline \multicolumn{2}{|c|}{$\begin{array}{l}\text { Group III: Language and Society/Language and the Mind ( } 8 \text { credits) } \\
\text { Students may choose EITHER } \\
\text { - } 8 \text { credits from either category } \\
\text { - } \quad \text { OR } 4 \text { credits from each category }\end{array}$} \\
\hline Language and Society & $\begin{array}{l}\text { LING 532: Sociolinguistics } \\
\text { LING 580: Bilingualism } \\
\text { LING 581: World Englishes } \\
\text { LING 582: Pidgins \& Creoles }\end{array}$ \\
\hline Language and the Mind & $\begin{array}{l}\text { LING 533: Psycholinguistics } \\
\text { LING 537: First Language Acquisition } \\
\text { LING 545: Linguistics \& Cognitive Science }\end{array}$ \\
\hline \multicolumn{2}{|c|}{ Group IV: Research Studies and Culminating Experience (12 credits) } \\
\hline Required courses: & $\begin{array}{l}\text { LING 559: Introduction to Graduate Study (2 credits) } \\
\text { LING 560: Research Design ( } 2 \text { credits) } \\
\text { LING 561: Research Methods ( } 2 \text { credits) } \\
\text { Cul mi nating Experience ( } 6 \text { credits) }\end{array}$ \\
\hline
\end{tabular}

Table 1: Overview of program curriculum 
Although one of the categories for elective courses is Foundations in Language and Linguistic Theory, the program does not specialize in theoretical linguistics. Of the courses offered, Phonetics, Phonology, and Syntax are the only classes whose content would be considered traditional "theoretical linguistics." The majority of courses focus on more applied fields of linguistics. All linguistics courses contain applied theory, as do many of the language education courses. Despite the division of courses into groups, the subject matter in various groups overlaps and is interrelated. Students will encounter concepts in Second Language Acquis ition, for example, which will also come into play in courses like Psycholinguistics and First Language Acquisition.

A culminating experience is als o required. Students have three choices for fulfillment of this requirement. The thesis option requires students to design and conduct an empirical study. The project option addresses a practical problem or has a practical application to teaching. The comprehensive exam synthesizes know ledge gained in courses throughout the program. Students who choose the project or exam option must also take a class on empirical research writing (ERW), where they are required to complete a short research project on a topic of their choice. The graduate research sequence is designed to help students decide which option they want to choose for the ir culminating experience. Research Design and Research Methods are designed to help students pinpoint the topic of their thesis or empirical research paper and begin research on that topic by completing a literature review in the first course and a methodology section in the second. Thus, by the end of the second course, students have made great 
progress toward their thesis or ERW paper. Students typically take Research Design during their first or second year and Research Methods during their second year.

In addition to the ir culminating experience, students must construct a teaching portfolio that documents teaching, tutoring, and observation hours, lesson plans, and materials. Students begin constructing their portfolio as part of the TESOL Methods courses. See "Required Courses" below for a more detailed description of the Methods sequence and the portfolio.

The program has one prerequisite, Introduction to Linguistics. Some students take Introduction to Linguistics during the ir time in the program and others take it before their admission to the program.

The program also has two graduation require ments, English grammar and foreign language. Students must take two years of a foreign language at the university level or equivalent in order to graduate. Students may complete the English grammar requirement by passing a test, or they may take an English grammar course, Structure of English, during their first year in the program.

Courses in the Applied Linguistics department are generally crosslisted for graduate and undergraduate students. MA TESOL students take many of the same classes as students studying for a BA in Applied Linguistics, the exceptions being the graduate research sequence and Second Language Acquis ition. Class size varies. Several classes 
are large (50 to 100 people), but most consist of about 15 to 20 students. The courses in graduate research sequence are often smaller (about 9 students).

\section{Required Courses}

This section contains a more detailed summary of the courses most important to my study: required courses that my participants took during their first year and any elective courses relevant to the ir narratives.

Second Language Acquisition introduces students to prominent theories in the field of second language acquisition. Major assignments require students to practice gathering and analyzing linguistic data, using methods based on different the ories of second language acquisition. The aim of this course is to introduce students to the analys is of learner language and to familiarize them with the ways in which people learn a second language.

Understanding the International Experience introduces students to issues in English as a global language and interactions between cultures. Major assignments require students to reflect on their own culture and come into contact with a culture different from their own with the goal of developing self-awareness and intercultural competence.

Methods for TESOL is a two-quarter sequence that focuses on the development of pedagogical skills. Course readings focus on pedagogical theories specific to the ESL field. Students are required to tutor, teach, and observe ESL classes. They must also write 
lesson plans, teaching philosophy statements, and reflective statements, with the goal of constructing a portfolio. Students create a final version of this portfolio within two terms of completing the Methods sequence. The final portfolio must be approved prior to graduation. Methods students must complete a total of 70 hours of teaching, tutoring, and observation combined for their final portfolio. Fifteen hours of observation, seven hours of tutoring, and either one or ten hours of teaching must be completed during the Methods sequence; the rest of the required hours must be completed independently within two terms of finishing the Methods sequence. See Appendix $\mathrm{C}$ for a list of the requirements for the Methods teaching portfolio.

Introduction to Graduate Study introduces students to research in Applied Linguistics. Students practice reading and analyzing a series of research articles representing different methodologies and areas of interest in the applied linguistics field. They are also exposed to guidelines of academic writing in the social science field.

Research Design builds on know ledge gained in Introduction to Graduate Study, introducing students to research methods. Students are encouraged to choose their culminating experience during this course. Major assignments require students to formulate research questions and write a literature review on a topic re levant to their thesis or final research paper.

Research Methods provides more in-depth study of quantitative and qualitative methodology and research design in Applied Linguistics. Students are required to write a draft of a methodology for either the ir thesis or the ir final research paper. Students read 
and re-read the same articles and textbooks throughout the graduate sequence with the intention of deepening their understanding of qualitative and quantitative methodologies, how research is structured, and how to conduct research on their own.

Entering MA TESOL students are encouraged to take Second Language Acquisition, Understanding the International Experience, and Introduction to Graduate Study during the ir first term; these classes are prerequis ites for many of the courses in the program. The majority of first-year MA TESOL students take Methods I during their second term and Methods II during their third. Many also take Research Design during their third term.

Many MA TESOL students a lso choose to take the Community Practicum. This is an elective course in the Language Education/Applied Linguistics Theory category of program curriculum. It enables students to design curriculum for and teach an adult community ESL class twice a week for two months. These classes are offered in the evening at public schools in the community. The practicum combines weekly class sessions, where students interact with other student teachers and the ir supervising professor, with hands-on teaching in low-income communities in the area. Students are required to write lesson plans and reflections for each class that they teach during the practicum. They are also required to design teaching materials and needs assessments for their students. 


\section{PARTICIPANTS}

The study participants were four first-year MA TESOL students in the program, all between the ages of 20 and 30. Three of the participants were female, and one was male. The ratio of male-to-female participants in my sample group was a fairly accurate representation of the larger ratio within the program.

All four participants were native speakers of English who grew up in the United States. None of my participants were international students. Three of the four had teaching experience: Rebecca taught EFL abroad to Japanese high school students for two years, Lisa taught EFL to Spanish-speaking adult women in Argentina for a year, and Jesús taught EFL to adults in Costa Rica for a year. The fourth participant, Dor is, had no experience teaching ESL or EFL at the beginning of the program.

I selected participants based on their official admission into the program as of the beginning of Fall term 2011 as well as the classes they were planning to take during their first year. My intention was to target a group of first-year students taking core curricular courses in the sequence recommended by the department, i.e., students taking Second Language Acquisition, Understanding the International Experience, and Introduction to Graduate Study during their first term and the Methods sequence during their second and third terms. All of my participants met these criteria, though one had taken one of the required courses during the previous summer rather than during Fall term. I also made an effort to recruit both male and female participants from a variety of backgrounds in order to get a rich array of experience and perspective. I recruited my participants by speaking 
about my thesis at the MA TESOL graduate student orientation prior to the beginning of the school year. Participants chose their pseudonyms during the first interview.

I also interviewed the department chair and instructors of core classes in order to gain a better view of their understanding of the program's structure and content.

This project was approved by the university's Human Subjects Research Review Committee. The core participants and instructors signed Informed Consent forms at the time of the first interview. Methods students signed informed consent forms at the time that I described my study to the ir class.

\section{DATA SOURCES AND COLLECTION}

Participant interviews were my primary source of data. I met with each participant 2-3 times per quarter, generally once near the beginning of the term and once near the end, though scheduling difficulties meant that some interviews occurred closer to the middle of the term. Each semi-structured interview was guided by questions about the participants' experience with the program and required courses as well as by questions about their personal experience as a student and a teacher. Initial interviews also targeted information about the participants' background and beliefs about teaching. I asked questions such as What do you think constitutes a good teacher? Why? My questions were designed to elic it information useful to my research questions, but were also designed to be open-ended enough so as to avoid leading my participants. I avoided asking students to make value judgments about the program or specific courses, instead 
asking them what they had/had not found interesting or helpful to them as teachers. In subsequent interviews, the questions were more open-ended and were guided by topics that students initiated. In some cases, students chose to talk about extracurricular experiences and factors. On average, the interviews lasted about 20-30 minutes. The shortest interview was 9 minutes long, while the longest lasted about an hour.

In addition to the beginning- and end-of-term interviews, I conducted a group retrospective with all four student participants at the end of the study. This was an openended discussion of the first year of the program and the participants' collective and individual experience. I had no prepared questions for this interview. The only guideline I gave to partic ipants was to discuss the ir experiences in various classes and in the program as a whole. I recorded each interview with a digital voice recorder and later transcribed it orthographically.

I also interviewed the department chair and instructors who had taught required classes. These interviews were more structured than the student participant interviews and were based on questions designed to target program goals and the reasoning behind certain courses and materials. I asked questions such as What areas of the program goals do core assignments target? What is the reasoning behind these assignments being structured as they are? Interviews with instructors were conducted near the end of the 2011-2012 school year and were also recorded and transcribed. I did not use data from these interviews in my results chapter, as it was not directly related to my research 
questions. However, I did use it in the conclusions and implications chapter as a supplement to my results.

Conducting interviews with instructors in the program also aided me as a researcher. Because I had only experienced the program as a student, it was helpful to me to understand the pedagogical goals of program curriculum from instructors' and administrators' point of view. Being aware of the program's agenda helped me combat researcher bias because I was not relying only on a student's point of view of the program. I was therefore able neutralize some of my own past frustrations and sources of bias as a student, minimizing the like lihood that my own impressions of the program would bleed into my conclusions about student data. I was able to look at my data more objectively as a result of having input from students and instructors both.

I also used program documents, such as the program's statement of goals and objectives, the syllabi of required classes, and require d course readings in my analys is. Examining these materials for content helped me understand the structure, require ments, and goals of the program and the required courses, giving me a better appreciation of the backdrop for my research.

\section{DATA ANALYSIS}

Data were analyzed using in vivo coding. There were two parts to my analys is.

First, I analyzed interviews by partic ipant, coding each participant's interviews individually. Though coding emerged based on themes apparent in the data, I targeted 
themes that had to do with beliefs about teaching and teaching ESL in particular, as well as themes that had to do with the students' experience in the program. In order to determine if change in belief occurred, I compared themes across time, beginning with the first set of interviews. This section of the analysis focused chiefly on describing the individual experience of each core participant.

The second part of my analysis consisted of a discussion of themes across participants. I divided themes into two categories: those which had to do with my first research question, What change, if any, do PSTs report in their beliefs about teaching throughout the course of their first year in the program? and those which had to do with my second research question, How do PSTs relate their changes in belief to the program curriculum (course content, course sequencing, course structure, etc.)? To what extent do they also relate their changes in belief to factors outside of the required curriculum (affective factors, additional teaching experience, interactions with classmates, etc.)? I also noted significant themes which did not directly correspond to either research question but which emerged nonethe less.

In making interpretations and drawing conclusions, I supplemented my analys is with a discussion of the course goals as defined by department instructors and department documents. I compared data from these documents with the data from the student groups. My intention in doing this was to see whether the students' experience was similar to the goals the program had set out for students and what implications this had for the program. 


\section{RESEARCHER ROLE AND TRUSTWORTHINESS}

At the time of this research, I was a second-year student in the program, giving me both researcher-as-participant and researcher-as-observer status. An advantage of this status is that I was familiar with the courses taken by participants and had taken them myself the previous year; I was also familiar with the program structure and instructors. I had an insider's view of what it was like to be a first-year student. However, I was removed enough from the actual design of the curriculum in that I did not have insider knowledge of its goals and design. Likewise, I was an outside observer of the cohort I studied. I did not take any core curricular classes at the same time as study participants, and I had little to no interaction with study participants outside of interviews.

My involvement in the program was an advantage because it gave me easier access to instructors and participants as well as insight into the experience of the student participants. However, there was also the danger that my own experience as a student in the program would bias my coding of the data. There was also the danger that my own bias would shape interview questions to target information that was in keeping with my experience in the program. In order to combat this, I made interview questions as openended as possible. The direction of each interview except the first (which had to establish student beliefs) was determined by what the student wanted to discuss, with the only guideline being that it had to be about the ir experience during the term in which the interview took place. 
I faced two major difficulties as a result of my role as a student in the program. The first, which I mentioned above, was researcher bias. In my analys is of the data, I saw patterns that mirrored my own experience as a first-year student. It was difficult for me at times to separate what I believed about the program from the opinions that my participants were expressing. I found it necessary to repeatedly revise my Results and Conclusion chapters in order to minimize the presence of my own opinion in my conclusions. Constant reflection and conversations with my thes is advis or helped me identify my bias and keep it as distanced as possible from my interpretation of the results. Interviews with instructors were also invaluable in providing me with different points of view on program curriculum. As I discussed above, through compiling different points of view — not only those of students - I was able to remove myself from my own experience of the program and to look at my data more objectively. I was able to adopt a researcher's perspective rather than the perspective of a former first-year student.

I also found it difficult to present critic is ms of the program in a way that was fair to students and faculty. As I will discuss further in my Results and Conclusion chapters, many of my participants had strong opinions about the graduate research sequence. I used the information I had gained from instructor interviews and program documents to balance out these opinions and acknowledge the presence of issues that my participants had not discussed. 


\section{CHAPTER 4: RESULTS AND DISCUSSION}

\section{INTRODUCTION}

In this chapter, I discuss the results of my study. In the first section, I discuss the experience of each student participant one-by-one, focusing on the narrative of the ir first year in the program. In the second section, I interpret the results from participant narratives in terms of my first and second research questions, ending with a summary of important themes that emerged in the results.

\section{RESULTS}

\section{Rebecca: Building confidence as a teacher}

Rebecca entered the program with five years of experience teaching EFL in Japan. She had taught a variety of ages, from kindergarten to adult, but had not liked the teacher-led approach prevalent in that environment (Interview 1, October 6, 2011). She had chosen this program mainly because she had friends and family on the West Coast and wished to stay near them. She had little interest in Applied Linguistics, wanting to focus mostly on building her abilities as a teacher (Interview 1).

Rebecca expressed a lack of confidence in herself as a teacher and a shyness in interpersonal interactions (Interview 1). Rebecca's shyness at the beginning of the term was compounded by what she called "reverse culture shock" (Interview 1). She had been 
in Japan for such a long period of time that coming back to the United States seemed strange and unfamiliar.

During the first interview, I asked Rebecca what she believed constituted an effective student and an effective teacher. Patience was the most important quality that she believed a teacher could have. This belief, she said, was shaped by her experience in Japan, where "you teach something, [you get] nothing from the students. You kind of get a little irritable, so you have to learn to be patient with them" (Interview 1). She cited motivation as the most important skill a student could have, specifically, having an interest in the material being taught.

Rebecca's experience of the first term was large ly an experience of learning to be a student again (Interview 2, December 2, 2011). She reported feeling frustrated and overwhelmed by what she described as a lack of structure in her courses (Interview 2). Although she found her classes interesting, she reported having a difficult time processing information because of the lack of time and the lack of organization in course content. She also found the "research-heavy" nature of the first term to be "unmotivating" (Interview 2). She dis liked Introduction to Graduate Study, largely because she had no interest in what she called "research theory" (Interview 2), i.e. course content that was not directly applicable to teaching English. She als o expressed concern about being required to take more linguistics courses in the future.

However, Rebecca did find some of the concepts brought up in Second Language Acquisition and Understanding the International Experience interesting and applicable to 
her career as a teacher. She enjoyed learning about interactional theory. The concept of world Englis hes was also interesting to her as someone who had taught in an environment where American English was considered the ideal (Interview 2). She did not cite any change in herself as a teacher at the end of the first term, but did acknowledge that she had taken some useful information away from her classes and was "getting the hang of" being back in school (Interview 2).

Rebecca began to cite change in her development as a teacher during the second term of the program. One of her most significant experiences during the second term that influenced her development as a teacher was an observation assignment for Methods I. Rebecca chose to observe one single teacher throughout the entire term. Rebecca reported that the teacher she had observed had "inspired" her (Interview 3, February 10, 2012) by embodying many of the characteristics that Rebecca considered herself to be lacking as a teacher:

[She] is very confident and she's always on top of questions, she can explain things well, which is a thing I have problems with sometimes, and I like the dynamic she has in the class, because students are always trying to give answers, and she facilitates that very well....Instead of in Japan, when I taught, a lot of teachers just gave answers, it doesn't really allow stude nts to process and develop their own learning (Interview 3).

Another positive experience that Rebecca had during this term was tutoring a university student in ESL. Her tutee was "the best tutee"; he was "so proactive 
and...really motivated to learn English" (Interview 4, March 9, 2012). Rebecca was able to work with her tutee to find ways of practicing English that interested him, rather than just working out of a textbook. This kind of tutoring appeared to appeal to Rebecca's beliefs about teaching, as well. She was able to let her tutee direct his own learning while she acted as a facilitator. She was also developing a rapport with him and appeared to be moving beyond her shyness. She reported making friends with her tutee and with some classmates (Interview 4).

Teaching in the Community Practicum, which Rebecca took during her second quarter in the program, also appeared to influence Rebecca's development as a teacher. It was "the best class" (Interview 4). She was able to apply new approaches and techniques that she had learned in Methods, reflect on teaching, and develop as a teacher. She found the practicum to be the perfect environment for experimenting and developing her skills. 'I think that's a very good environment to just try out things and just experiment. And, you know, it's okay if you fail, it's just like, okay, this thing didn't go well, reflect on it, what can I do to improve...it's what teaching is all about" (Interview 4).

Rebecca mentions the reflective aspect of coursework in the above quote. This was something she repeatedly cited as being helpful for her in terms of developing a perspective on teaching and coming to terms with her own identity as a teacher. 'I'm actually learning theories and other perspectives...I can kind of make sense of things that I've done, and then think like, 'Oh, well I could have done that differently"' (Interview 3). 
Rebecca did not explicitly discuss the effect - if any — that the content of linguistics courses, as opposed to pedagogical courses, had on her teaching. She continued to prefer practice over research and to express a lack of interest in doing research in linguistics. However, she was beginning to discuss how pedagogical theory helped her as a teacher-in-training. This is a marked difference from her first interviews, where she reported disliking all theory. Pedagogical the ory from various courses he lped her identify and work on what she saw as some of her problem areas as a teacher (Interview 6, June 13, 2012).

Despite cons istently expressing dis like for research, Rebecca reported finding a new appreciation for and interest in Computer-Assisted Language Learning (CALL) as a result of a research project she had to do for Methods II (Interview 6). Reading articles on CALL prompted her to think about how she could implement technology in her own classes. She found that the research was "starting to get me into my little niche.... Like what [are] my real interests? Technology in teaching is one of them, so that really helped me confirm that, yes, that's what I want to do" (Interview 6).

\section{Final Interview}

In the final interview, I asked Rebecca to look back at her quotes on be liefs about effective teachers and students and tell me if they had changed. She reported still agreeing with her belief that patience was important for a teacher. She also added, however, that "knowing how to balance implicit teaching and explic it teaching" was an important skill which she had gained appreciation for during the year (Interview 6, June 
13, 2012). Her experience in Japan was "explic it, explic it, explic it," and she wanted to move beyond that (Interview 6).

Other new skills that Rebecca cited as important for a teacher were "being responsive to student needs" and "portraying confidence" (Interview 6). Both of these, she believed, could be helpful for motivating students. "That can help motivate them to finish the class and the material, if they have a really good teacher that's there for them and they know that they can go to them....If a teacher's confident, you can learn from them" (Interview 6).

Both of these new beliefs about teacher skills came from Rebecca's observations during Methods I and II, she said. Observing a confident teacher who was responsive to her students and made it known that their needs were important had made her appreciate these as important skills.

She also expressed a more specific and refined preference for approaches to teaching. "I like to do a mix of inductive and deductive teaching. I don't really like to give everything away to my students....I prefer only a little guidance, just letting them figure it out, I think that's what I learned most this term" (Interview 6). This was a new development in Rebecca's beliefs about teaching. At the end of the year, more than at any other time, I saw her express a concrete opinion about how she believed she should teach, and why. Although she had expressed a dis like for a strictly teacher-fronted classroom in her first interview, she had not expanded on what her preferred teaching environment would be. In her final interview, she not only expressed a definite preference, but she also 
demonstrated that her own identity as a teacher was linked to this preferred role through the use of first-person language.

Rebecca's belief about what makes an effective student also differed from what she had expressed in her first interview. Instead of citing only motivation, she said a good student was "proactive in the ir own learning" and had "learner autonomy" (Interview 6). She had learned this from working with her tutee, who was always willing to "take it outside of the classroom" and practice English on his own (Interview 6). "Stuff like that is just really great...gratifying for the teacher" (Interview 6).

In the final interview, I asked Rebecca if she felt that she had changed as a teacher. She believed that she had. She had learned to incorporate new knowledge about linguistics and pedagogy into her approach to teaching. "[C]oming here, I learned about theories, and it was like, oh, I can see how those theories actually relate in the classroom now" (Interview 6). (It is worthwhile to note that Rebecca referred to any aspect of coursework that was related to linguistic disciplines as "theory"). It also appeared that she felt better-equipped to plan lessons and to teach in different contexts, having taught in the community practicum and substituted for a class at the Intensive English Language Program at the university.

About her confidence as a teacher, Rebecca said:

My friend told me something when I made a presentation last week, "You just look so confident up there when you're teaching." I don't 
know, I guess it's just different when I'm teaching. In real life...I'm still very shy. But my friend saw something different when I'm in front of the class (Interview 6).

At the beginning of the year, Rebecca's experience with teaching had been limited to a single context, and her beliefs were shaped by that conte xt. During the course of the year, she taught and observed in different contexts, encountered new theories, and practiced reflexivity as part of the program content. The combination of these experiences contributed to a deepening of her know le dge and a more refined sense of what she believed and what she wanted to embody in the future as a teacher. She finished her first year more aware of her preferences for teaching environment and methods. She also de monstrated a greater awareness of what she was looking for in a student and what kind of skills and approaches she would apply to bring out student motivation.

\section{Lisa: Teaching as a social service}

Lisa came into the program with strong beliefs about teaching but with some uncertainty about whether she wanted to teach as a career. She had experience working overseas as part of a community program for low-income families in Argentina and had done a good deal of tutoring, both one-on-one and in groups, with youth and adult refugees in the United States (Interview 1, October 9, 2011). Lisa's ma in goal for the program was to gain a degree that would enable her to find jobs in a variety of different areas. She expressed no interest in the linguistics element of coursework, but saw the 
program as a way to network and expose herself to teaching opportunities in the community (Interview 1).

Lisa saw teaching ESL as "a pretty great expression of hospitality to folks who come here from other countries" (Interview 1, October 9, 2011). She had been torn between a career in social service and one in teaching, but knew that she wanted to work with women and disadvantaged youth.

In addition to her obvious passion for helping others, Lisa believed that the best skill a teacher could have was flexibility. She also cited what she called "dynamic teaching styles," where student input was important and teacher development was an ongoing process (Interview 1). She attributed these beliefs to her own experiences as a student. She preferred to have teachers whose lessons were full of activities and were empowering for the students, rather than a traditional lecture environment (Interview 1).

Lisa cited motivation as the most important skill a learner could have. This belief had been shaped by her experience as a teacher. "I was just completely uninterested in working with students who didn't want to learn” (Interview 1). She decided to shift her career path to focusing on working with refugee groups because "this intense motivation, that they just want to learn and need to learn...I love that" (Interview 1).

Lisa's first term in the program was extremely stressful and frustrating (Interview 2, December 10, 2011). She described Fall term later as "the great abyss...it was so terrifying, it was so terrible, it was so much work and it felt so unhealthy and 
imbalanced" (Interview 4, March 20, 2012). She enjoyed some of the concepts presented in classes, especially Understanding the International Experience, but she was frustrated by the volume of work and the lack of time for discussion or processing of information. Lisa did not report encountering any specific course content that she believed would be useful to her as a teacher, but she did find some of the course content interesting. Lisa felt that her ability to actually process information during the first term was hampered by her stress level and her lack of a background in linguistics. She expressed a desire for more time for in-class discussion, particularly in Understanding the International Experience. At the end of the first term, Lisa continued to question staying in the program (Interview 2).

One of Lisa's chief sources of stress during the first term was her lack of background in social sciences and linguistics in particular (group interview, June 6, 2012). Lisa had one course on her undergraduate transcript that the department accepted as an equivalent to Introduction to Linguistics, but it "was supposed to be a linguistics course for my Tesol [sic] minor, but they were phasing the minor out, so an English prof taught it and we didn't learn any linguistics" (Personal correspondence, March 21, 2013). This meant that Lisa took Second Language Acquisition and subsequent linguistics courses without a valid prerequisite.

Like Rebecca, Lisa had the tendency to group any course content re lated to linguistics or research into the category of "theory," which she saw as unfamiliar and unre lated to teaching. Though Lisa did report being aware that there was a connection 
between theory and practice, she felt that her stress level and her unfamiliarity with the material prevented her from being able to find that connection (Interview 2).

During the second and third terms, Lisa began to have more positive experiences that she cited as contributing to her growth. One of the most significant contributing elements was interaction with her peers; specifically, interaction in smaller groups required for Methods projects. “Because I didn’t feel like we were able to talk very much in class...it was kind of neat to have like our own space each week to actually talk about things in smaller groups" (Interview 3, March 7, 2012). She also found that be ing able to work in groups was "very empowering" and helped her process the material introduced in class: "we were just able to take the text and really grapple with it together, and just talk about the implications for ourselves" (Interview 3).

Lisa als o saw the Methods observations as having been helpful to her as a developing teacher. She was able to identify traits and techniques that she did not want to embody in her own practice. She was also able to talk with instructors and identify their reasons for doing the things they did. "I felt like I was able to get some pretty explicit advice on how to teach, it was just really he lpful" (Interview 3).

Another major contribution that the Methods sequence made toward Lisa's development as a teacher was reconfirming that she did, in fact, want to teach: "Methods has allowed me to explore whether or not teaching is something I' $m$ interested in, and I found that it was" (Interview 4, April 12, 2012). 
Lisa also reported having a positive experience in the elective class she took during her second term. Being able to take sociolinguistics was "so fun" (Interview 4). She enjoyed having the freedom and the time to thoroughly experience the content of a class that was personally interesting to her. Despite her lack of a background in linguistics, Lisa found that the content of the sociolinguistics course addressed many issues that she found compelling, such as the social implications of accent and dialect (Interview 4). This was a shift from her previous conception of linguistics courses being a source of stress and unrelated to the practice of teaching.

During her third term, Lisa took the Community Practicum, which was also a positive experience. She found that writing reflections after each class and being required to write lesson plans was very helpful for her: "I think for me just having the organization of the class, and those lesson plannings, and those reflections....I was like, oh man, that's so exactly what I want" (Interview 4). Lisa knew that her own learning style was "off the charts on reflection and experience," so she felt very excited to be taking a class where she could not only experience teaching firsthand, but also reflect on it regularly (Interview 4).

She was also able to reflect on her own learning style and how it might influence her teaching. This was a new consideration for Lisa, brought about by a learning styles inventory assignment in Methods II. She had come into the program aware of her own learning style, but talking with her classmates and seeing how each learned differently had given her a new perspective. "I think that helped me be aware of my own learning 
style, and also just supporting students, being very mindful of students that are more introverted and wouldn't really enjoy some of the activities that I might design" (Interview 4).

\section{Final Interview}

In her final interview, Lisa cited another change in her perspective on teaching and learning: a newfound appreciation for preparedness. Lisa said that the practic um contributed greatly to this:

The practicum showed me the value of preparation, because most of my experience had been pretty disorganized, and I had generally not been very prepared. I think the practicum showed me, wow, I spent a lot of time preparing, and I had a lot of different contingency plans... and it seemed really valuable, [it] really did a lot for a valuable experience for the students (Interview 5, June 29, 2012).

Lisa still agreed that flexibility was an important skill, but "probably not to the same extent" as she had at the beginning of the year (Interview 5). "Even if you're flexible, but you're not coming prepared with some kind of plan and multiple contingency plans,... it still might not be a very valuable class session for the students" (Interview 5). She continued to believe that attentiveness to student needs was also important. Her new focus on preparedness, however, indicated that she had rethought and added to her beliefs about teaching. 
In terms of important skills for students to have, Lisa said that "motivation will completely color the learning experience"; however, she added that "it's much more complex than how we paint it, so it's not something that we can just transfer to students, give students, but we can understand the ir situations and capitalize on what they are bringing to class" (Interview 5). Her understanding of motivation had been reshaped by an article she had read which discussed investment instead of motivation, and this was a view that Lisa preferred. "Investment takes more of a look at the types of resources that the students are bringing to the class and what they hope to get out of it. And to me it encapsulates a little bit more of, it's not just a choice, there are a lot of extenuating factors" (Interview 5).

Lisa entered the program with a very strong sense of her own preferences as a learner and teacher, as well as a strongly-defined set of beliefs about what teaching stood for and what skills teachers and learners should have. During the course of the term, she was able to gain new appreciations and to add nuance to her beliefs. Some of her learning took place as a direct result of program curric ulum, but a good deal of it was reflective and internal, or based on interactions with her peer group.

During the course of the first year, Lisa began to examine her own teaching style from a more critical point of view, looking at how her experiences and natural proclivities toward learning had shape d her as an instructor. In addition to this, a major change that Lisa went through was discovering that she was indeed interested in teaching as a career. Whereas she had felt uncertain about it at the beginning of the year, she 
ended the third term feeling like teaching was something she felt passionate about and wanted to continue pursuing (Interview 5).

\section{Jesús: Rediscovering the passion for teaching}

Jesús began the program with experience as a substitute teacher in a variety of subjects. His only experience teaching English was from a year-long EFL program in Costa Rica. He said that he had been drawn to teaching after working with Mexican immigrants and seeing how motivated they were to learn and practice English (Interview 1, October 5, 2011). He had been thinking about teaching as a career for some time, and finally "I went... and taught to see if it was something I liked. I loved it" (Interview 1).

Jesús's main goal for the program was to get an MA in order to have an advantage applying for jobs. He expressed no interest in the linguistics or research-related aspects of the program.

When I asked Jesús what he thought was the most important skill a teacher could have, he cited "patience, in a broad sense, just kind of understanding that people are all learning at different levels" (Interview 1). He also said that confidence was an important skill to have. He based this be lief on his experience in Costa Rica, where his students had looked to him "in a very trusting way" as an expert on English and he had felt the need to portray confidence in order to match the ir trust (Interview 1).

Jesús cited motivation and a willingness to practice "anytime, anywhere" as the most important skills that a student could have (Interview 1). He said that this belief was 
shaped by his experience as a language student learning Spanish. He had had to push himself to practice and to actually use his target language, and knew how important it had been to his learning.

The first quarter, according to Jesús, was “insanity” (group interview, June 6, 2012), and he did not see any change in himself or his beliefs. However, he could imagine change coming later on as a result of readings and the assimilation of new concepts: "I can see those things...happening sort of subconsciously....none of it's cemented in anywhere" (Interview 2, December 6, 2011). He felt that he had gained a good deal of knowledge, but that it was not yet explicitly influencing his teaching.

Jesús found that discuss ing concepts and class material with his peers was helpful for processing the material and finding new perspectives. He was somewhat frustrated by the "subjective and experience-based" nature of many classes (Interview 3, March 8, 2012) and the difficulty of getting a "fully holistic view from just one teacher" (Interview 3). He told me that working in groups and "having people throwing in the ir two cents and everyone is speaking pros and cons" was a helpful way to look at concepts from different perspectives that were not presented in class.

During the third term, Jesús experienced a good deal of frustration with program requirements. He was taking the second course in the graduate research sequence, Research Design, which required him to begin designing research toward his culminating experience. Jesús did not feel like he was able to focus on developing as a teacher; rather, he felt pressured to work on his culminating experience in order to graduate in two years, 
but simultaneously not interested in working on it. "I have no interest in doing research. It's a waste of time" (Interview 4, March 30, 2012). He acknow ledged that it had been helpful for him to learn how to read research, but he felt like "it's read what you want and get what you get out of it....I feel like most of my focus should be on teaching and enough is enough with the research" (Interview 4). Like Rebecca and Lisa, Jesús appeared to be grouping the coursework in the Graduate Research sequence together with any coursework related to linguistic disciplines. He did not appear to make any explic it connection between research, linguistics, and practice, rather seeing research and linguistic coursework as an impediment to him pursuing his interest in teaching.

Jesús reported that he had lost his interest and passion in the program as a result of what he saw as a focus on research (Interview 4). He was now only interested in getting through the program so that he could get a job: 'I' $m$ paying a lot of money and...I'm here for a specific reason. I'm here to get a degree for more opportunities career-wise" (Interview 4).

This was also the term in which he took the Community Practicum, which he called "a saving grace" (group interview, June 6, 2012). Jesùs appeared to view the practicum as separate from the rest of program curriculum. He felt that he enjoyed it much more than any of the other classes he had taken. He found the regular feedback from the supervising instructor extremely helpful to him as a teacher, and that teaching in the practicum had given him experience "fine-tuning lesson planning and working in a very different context" from what he was used to (Interview 4). What appealed to him 
most about the practicum, however, was simply the opportunity to teach: 'I've had countless days where I just wanted to say, 'Fuck this,' and now be ing able to teach on a daily basis, it's the only time I come home happy from school" (group interview, June 6, 2012). Taking the practicum had helped him rediscover his excitement for teaching. "Being able to teach again has been nice. It's a reminder that I leave there feeling good, I leave there feeling like that's why I'm here in the first place" (group interview).

\section{Final Interview}

When I interviewed Jesús at the end of the term, he still agreed with his original beliefs about teachers and students. He added that organizational skills were important; this was something he had learned from the Practicum (Interview 5, June 23, 2012).

Jesús felt that he had developed somewhat as a teacher, mostly due to the practicum and readings from Methods. 'I think I'm more consc ious of what I'm doing and what the students are doing and what might be happening beneath the surface in class" (Interview 5). He also felt "a lot more prepared, a lot more organized," and felt that he had improved as a teacher and a student (Interview 5). He did not cite any specific concepts from course curric ulum that had contributed to his development as a teacher.

Jesús displayed little change in his beliefs about teachers and teaching. His first year in the program was, ultimately, beneficial: "I'm thinking about the opportunity to become a better teacher, what's changed. With those things considered, I would say it's been a good experience" (Interview 5). However, it was also colored by frustration about 
academics and program structure: "I feel like a lot of people had different experiences going through it, [frustration] for me was the biggest one" (Interview 5). He found interaction with his peers helpful and greatly enjoyed the opportunity to teach. However, his lack of interest in research and linguistics appeared to influence and perhaps impede the deve lopment of his beliefs. He admitted to finding some course readings helpful, but never showed evidence of integrating concepts presented in class with the practice of teaching. The areas in which he reported the most development stemmed directly from his experience in the practicum. For Jesús, the realms of research and applied linguistics remained separate from the realm of practice throughout his first year.

\section{Doris: Coming intofocus as a teacher}

Doris was the only one of my core participants who had never taught before. She came from a background in linguistics, but had always wanted to teach "in some way" (Interview 1, October 3, 2011). Her primary interest in teaching ESL came from her experience as an undergraduate. She had found the apathy of her classmates in the university setting "very off-putting," and this made her want to teach in an environment where students would actually be passionate and motivated to learn. "Here are these immigrant and refugee populations...they want to learn English...that's a meaningful skill, it's teaching people who want to be there...making an impact" (Interview 1, October 3, 2011).

Doris reported that, due to her lack of teaching experience, she did not feel entirely equipped to state her beliefs about teaching and learning. However, what she had 
"absorbed second-hand" as a student was that a good teacher was adaptable and flexible, able to work differently with different groups of students, and had a presence in the classroom, i.e., was not "easy to walk all over" (Interview 1). She had formed these beliefs through her experience as a student, seeing professors who did and did not embody these important characteristics and observing how effective they were because of it.

Doris cited motivation as an important skill for a learner to have, but added that she would be "really interested in defining that," because she believed that her standards for motivation might be different from those of her pros pective students (Interview 1).

In contrast to the other participants, Dor is came from a background in linguistics, and did not feel significant stress about the academic aspects of the program. Moreover, she was the only one of my participants who entered the program interested in doing research in applied linguistics and in writing a thesis as her culminating experience.

Doris's first term in the program was, she reported, not as stressful as many of her classmates' because she had friends who had been in the program and had warned her about the heavy workload (Interview 2, December 1, 2011). Additionally, she had taken Understanding the International Experience during the summer, before officially entering the program, which lessened her workload. She reported enjoying the courses she took during the first term, though many of the concepts in Second Language Acquis ition were not entirely new for her (Interview 2). Her main goal at the end of the first term was to 
gain hands-on experience teaching so that she could put some of the concepts she had already learned into practice.

Doris's first experience as a teacher came in the second term, when she took the Community Practicum. She found that it was very helpful for her as a novice teacher, because it forced her to design all of her own lessons and materials and to prepare for all contingencies.

When you come in with no experience, it basically throws you in there. You have to sink or swim.... Other experiences you might have teaching, you'll have the curric ulum provided for you. You're going to have a textbook. You're going to have students who show up every class.... By taking all of those away, it really helps you build those coping skills for when things don't go right (Interview 3, February 2, 2012).

Other things that the practicum taught Doris were how to be flexible as a teacher: "just being able to think on the fly" (Interview 4, March 5, 2012). She also began to understand her role as a teacher and her presence in the classroom. She became more confident and began to understand that "I can be up there, I can have control and think on my feet" (Interview 3). Later she reflected, "That's, I think, half the battle, just walking into the room and pretending that you know what you're doing there" (group interview, June 6, 2012). The Practicum helped her "[come] into foc us as a teacher. I learned how I identified myself in front of a room full of students, I learned how I wanted to be 
perceived by my students, and how I wanted to forge relationships with them" (personal correspondence, September 29, 2012).

Doris also found that the Methods sequence was helpful for her. She enjoyed taking the practicum at the same time as Methods I, rather than the standard recommendation of taking it in conjunction with Methods II. The readings in Methods introduced her to different methodologies, theories, and approaches to teaching. She was able to take model activities from the textbook and adapt them to use in her class. The practicum was a laboratory in which she could apply and experiment with concepts from class. "That's what the practicum is for....I have that experience of designing [an activity] and implementing it and reflecting on it....Lots of personal growth and professional growth" (Interview 3, April 3, 2012).

She found the observation assignments in Methods helpful as well. It was interesting for her, having taught in a multi-level community context, to observe levelspecific, university-run ESL classes. "It was great, because I could see a lot of great ideas for if I am teaching a multilevel class" (Interview 4, March 5, 2012). Observing classes was helpful for exposing her to different contexts that she had not taught in. She did not appear to use the observations so much as a way to find examples of teaching methods and approaches that appealed to her. Rather, she used them to become familiar with different contexts and to reflect on how she, personally, would approach a single-level setting. 
A good deal of Doris's personal growth in the program, she said, came from faculty and student interaction. Talking with professors and other students gave her the feeling that she was not "going at it alone" (Interview 3). She told me that she did not belie ve her growth as a student and a professional would have been as great if she had not had the faculty as a sounding board, being able to "go back to the faculty and say, 'Hey, here's what I think about this. Can you give me your interpretation of what I feel? Okay, I didn't consider that perspective"” (Interview 3).

Peer interaction helped her as well, "just seeing where everybody else is" (Interview 3). It was benefic ial for her to hear the opinions of her peers and to discuss course content with them. Her peers were "the best possible resource for [me]" (personal correspondence, September 29, 2012) both in dealing with program stress and processing program conte nt.

Doris enjoyed the applied linguistic component of the program and reported feeling enthusiastic about doing research for her culminating experience (Interview 4, March 5, 2012). She did not have the same anxiety as my other participants about the theoretical aspects of the program. She intended to incorporate information gleaned from research about corpora into future teaching experiences. Her study of corpus linguistics gave her useful perspectives on language use in English and how to teach vocabulary (Interview 4). Doris was the only participant in my core group who explicitly tied applied linguistics to her development as a teacher. 


\section{Final Interview}

I conducted the final interview with Doris via email because she was not available to interview in person. In the list of questions I sent her, I asked if she still believed that flexibility, adaptability, and presence in the classroom were the most important skills a teacher should have. Doris agreed with flexibility and adaptability "tenfold. I think when you're unwilling to change and unwilling to bend to new situations is when you lose effectiveness" (personal correspondence, September 29, 2012). She also agreed that having presence was important, but wrote that she was not sure what she had meant by "presence" — she interpreted it now as being "available to the students — as a mentor, an instructor, a pseudo-friend, [and] a fellow learner" (personal correspondence, September 29, 2012). This was a different interpretation than her definition of presence during the first interview. Then, she interpreted it more as a sense of confidence, whereas in the final interview, her understanding of presence had changed to accommodate a variety of roles that she believed a teacher should be able to take on in the classroom.

Doris further dis played a deepening understanding of teacher roles when she wrote that students should "drive the flow of a class, but the teacher is there to moderate and control" (personal correspondence, September 29, 2012). This was the first time in our interviews that she had explicitly expressed a belief about what teacher and student roles were in the classroom.

Motivation was still an important factor for students, Doris wrote in the final interview. However, she be lieved that motivation "ultimately lies beyond the control of 
the teacher....The teacher can work to raise motivation, but ultimately that is something that comes from the student themselves" (personal correspondence, September 29, 2012). Like the above quote, this indicated more definition in Doris's concept of teacher-student roles. She appeared to be moving beyond the more vaguely-defined beliefs of her first term to a strong, experience-based set of core beliefs that she would use in practice.

Doris credited the practic um with the majority of her change and growth as a teacher:

I think the best possible way of learning how to teach may be going into the practicum, where you have very little, to find out about your core beliefs as a teacher. You discover more about yourself and your approaches in that class than anything else. And that got me ready to face my future teaching challenges (personal correspondence, September 29, 2012).

She also felt that some of the reflective assignments in Methods had been helpful in her development, though she added that "I do a lot of reflection on my own time already" (Interview 4, March 5, 2012). She enjoyed "using my own experiences to ga in a better perspective of what it is like to be in another role" (personal correspondence, September 29, 2012). By reflecting on her experience as a teacher and a student, Doris was able to form an opinion of what she wanted her role to be in the classroom and what kinds of approaches she would use in new, different contexts. 
Doris entered the program with no teaching experience, but she had preestablished beliefs about teaching that came from her experience as a student. During the first year of the program, she de monstrated growth in her own identity as a teacher, as well as a deepening understanding of what she believed a teacher's role to be. At the start of the year, Doris's understanding of flexibility and adaptability was shaped by what she had seen as a student. At the end of the year, she understood those concepts on a deeper level, from a different side of the classroom. Having experienced what it was to be flexible and adaptable as a teacher made her define those terms not only differently, but in greater depth.

The scope of Doris's beliefs about teaching changed dramatically during the course of the year. She went from seeing teaching only from a student's point of view to seeing it from a teacher's and a student's point of view. This enabled her to develop more nuanced beliefs and to find her own identity as a teacher.

\section{DISCUSSION}

The following section discusses results from student narratives in terms of my first and second research questions.

Research Question 1: What change, if any, do PSTs report in beliefs about teaching throughout the course of the ir first year in the program?

A prevalent theme that emerged in the analysis of my participants' narratives was what I chose to call an "evolution" of the ir beliefs about teaching. At the end of the year, 
all participants reported agreeing with the beliefs that they had expressed during their first interview. There was no direct contradiction or refuting of previous ly-expressed beliefs that I could see. Nevertheless, the comparison of participants' beliefs at the beginning and end of the year does suggest that their beliefs deepened and developed over time. I chose to call this an evolution of beliefs because, although participants' final beliefs retained some similarities to those expressed in the first interview, they also became deeper, more specific, and more nuanced.

Evolving beliefs began with a concept, often loosely defined, which grew over the course of the year. Beliefs changed in scope (e.g. from a student-centric perspective to a perspective that took into account teacher and student roles) and specificity of definition. An example of this would be Lisa's definition of "motivation." During the first interview, she defined motivation as "wanting to learn" (Lisa, Interview 1, October 9, 2011). At the end of the year, her definition of this term had evolved to take into account students' resources, background, and agenda and how these contributed to the ir willingness to learn.

PST beliefs also appeared to evolve by taking on new concepts and ideas. Rebecca's beliefs about teaching in her first interview were somewhat similar to those that she expressed in her final interview, but she had added new skills that she thought were important. The addition of these skills greatly deepened and expanded Rebecca's beliefs about what made an effective teacher. 
Aside from change in explicitly-expressed beliefs, there was also evidence of change in other areas related to teaching and learning. This change was related to participants' skills and approaches as teachers, their conceptions of teacher/student roles, and the ir future goals for themselves as teachers.

My participants each reported some degree of new knowledge that they had gained and applied to the ir teaching. For some, this was the application of new skills, such as organization, lesson planning, or sequencing, that made teaching easier and more fulfilling for them. Rebecca used new language knowledge to help her teach grammar and pronunciation. Lisa found that having contingency plans built into her lessons helped with sequencing and time manage ment.

My participants also reported de velopment in their overall approach to teaching. Jesús gained awareness of classroom dynamics. Rebecca solidified her preferred approach to teaching. At the beginning of the year, she reported disliking teacher-fronted approaches, but did not discuss an alternative. At the end of the year, she demonstrated a definite preference for a collaborative approach where the teacher facilitated learning. Lisa reported a new awareness of different learning styles within the classroom which led her to design lesson plans that would address more than one style. Doris, having never taught before, had no solid idea of her approach to teaching at the beginning of the year. In her final interview, she presented a very solid concept of how she preferred to teach and what she believed her role in the classroom was. 
Doris's experience highlights another area in which change occurred:

participants' perception of themselves as teachers and their beliefs about teacher-student roles. The most dramatic change in this area can be seen in Doris's narrative. At the end of the year, she had a concrete concept not only of what she believed her role as a teacher was, but also of what she believed her students' role was. This progression is also evident in Rebecca's narrative. Although she began the year with experience teaching, she was reluctant to talk about herself in first person as a teacher. However, at the end of the year, she discussed herself as a teacher in first-person and presented a very clear view of what her role was and what approaches she enjoyed taking in the classroom.

Lisa and Jesús did not display a similar change in their perception of the ir own role as teachers. However, Lisa did display change in another area: her future career goals. Lisa entered the program unsure of whether she wanted to pursue teaching as a career. At the end of the year, she was much more confident that teaching was something she enjoyed and wanted to do in the future.

In addition to reporting an evolution in the ir be liefs, participants experienced change in their perceptions of themselves as teachers and their approaches to teaching. At the end of the year, each partic ipant reported to some degree that they had changed as teachers, either by gaining new skills, de veloping their identity, or solidifying their future career goals. Though not all of these changes were explic itly re lated to beliefs, many of them tied into participants' perceptions of themselves as teachers and their beliefs about what made a good teacher. Personal and professional de velopment had a link to beliefs in 
that it enabled participants to examine what they themselves valued as teachers and students. It als o allowed the m to identify areas for improvement and to identify new skills that contribute d to the ir de velopment. Participants experienced not only an evolution of beliefs, but an evolution of themselves in the ir role as teachers.

Research Question 2: How do PSTs relate their changes in belief to the program curriculum (course content, course sequencing, course structure, etc.)? To what extent do they als o relate their changes in belief to factors outside of the required curriculum (affective factors, teaching experience, interactions with classmates, etc.)?

My participants demonstrated change in two major areas: their beliefs about teaching and their beliefs about the ir own roles as teachers. Several factors contributed to these changes.

My participants reported finding the courses they took during the ir first term (SLA, Understanding the International Experience, and Introduction to Graduate Study) interesting, but they drew few connections between course content and the ir de velopment as teachers. Rebecca and Doris reported finding some concepts in SLA applicable to the ir practice, but they did not explicitly discuss SLA in later interviews. They did, however, use terms and concepts from SLA in later interviews. Likew ise, Jesús believed at the end of the first term that some of the concepts from his courses had been valuable, but he was not sure they had "sunk in" yet (Interview 2, December 6, 2011) — that is, he had not yet made a connection between what he had learned in class and what he believed about teaching. The lack of explicit connection that partic ipants made between course content 
and their teaching practice may have been due to a divide between theory and practice that emerged in the interviews. I will discuss this at further length below.

Rebecca and Lisa enjoyed Understanding the International Experience; both described it as their favorite class of the term (Rebecca, Interview 2; Lisa, Interview 2). However, they also both reported feeling frustrated by a lack of structure in the class and an imbalance between the amount of material covered and the lack of time in which to discuss it. I did see some evidence that Lisa carried concepts from Understanding the International Experience into subsequent terms. Lisa continued to pursue courses that dealt with the social implications of accented English and the nature of English as a world language (e.g. Sociolinguistics). She did not say whether these considerations had a direct impact on her teaching, however.

Courses in the graduate research sequence were a problematic element in many of my participants' narratives. Lisa and Jesús were both adamantly uninterested in doing research in applied linguistics. Lisa found the research sequence stressful because she had no previous expos ure to applied linguistics and reported having difficulty understanding the artic les. Jesús simply felt that it was “overkill” (Interview 4, March 30, 2012). He wanted more practical components to program curriculum and less focus on research.

One change that all four participants did attribute to the graduate research sequence was an improved ability to read research artic les and do graduate-level coursework. Two of my participants, Rebecca and Doris, also reported that doing research was helpful to them as teachers because it enabled them to learn more about 
areas they were interested in. It was unclear whether they attributed their new interest in doing research to the research sequence or to projects done for other classes.

Out of the required courses for the first year, participants mentioned the Methods sequence most frequently as contributing to their development as teachers. Rebecca and Lisa both discussed the benefit of the observations as a model for what they did and did not want to e mulate as teachers. They also both reported using the teachers they observed as a resource for advice and mentoring. Rebecca especially commented on the usefulness of having a teacher than she observed during an entire term who she could learn from and use as a model for her own deve lopment. Lisa and Rebecca, and Doris, to some extent, also credited the observation reports with prompting them to think about and reflect upon the classes they had observed. This was a useful tool for the ir de velopment, because it helped them see the reasoning behind activities as well as determining whether or not they would like to use those activities in their own practice.

My participants reported enjoying the Methods sequence and finding it useful. For a group of students so focused on practice, this is not surprising. Participants reported appreciating the practical skills and methods covered in the text. They also enjoyed having an open forum in which to discuss teaching with their peers and professors. Both the reflective elements of the Methods sequence and the social experience of being in a cohort of teachers-in-training appeared to contribute to my participants' accumulation of teaching knowledge. 
The Methods sequence appeared to have a direct link to my participants' development of the ir skills and approaches to teaching. It also appeared to influence the ir beliefs. Although my participants reported that the majority of their evolution in beliefs came from hands-on experience, the language many of them used when discussing beliefs was directly pulled from Methods readings on pedagogical theory. There was evidence in my participants language that they were integrating some theory into their practice, though not all of them seemed to be aware of it. Jesùs and, to a certain extent, Lisa, continued to view all "theory" as not useful, despite incorporating theoretical terms and concepts into the ir speech. Although they were consistently reflecting on their own knowledge as teachers, they did not appear to be reflecting on where this know ledge came from.

My participants attributed the majority of their changes in belief to the Community Practicum. The Community Practicum is not a required course for MA TESOL stude nts, so it is unusual that all four of my participants took it dur ing the ir first year. It appeared often in their narratives and seemed to have a significant impact on the development both of their beliefs and of their teaching practice. Several of my participants even cited it as their favorite class of the year and the class that contributed the most to their development as teachers. This was an example of a socially-situated teaching conte xt contributing to the growth of the ir knowledge. My participants appeared to need the actual experience of being a teacher in order to accumulate new knowledge about what it meant to teach. The hands-on teaching experience provided by the 
practicum appeared to be invaluable for my participants. Even those who had taught before mentioned that the unique context of the practicum was helpful for them to develop further as teachers. Jesús and Lisa both discussed the benefit of writing in-depth lesson plans and reflecting on the ir lessons after teaching them. This allowed them to develop their organizational skills and to be more thoughtful about how successful the ir lessons were in practice. This is significant in that both Jesús and Lisa also added the skill "organization" to their list of important skills for teachers to have. Their beliefs about what made an effective teacher were directly influenced by their experiences in the practicum.

Doris discussed the helpful nature of the practicum as a space in which she could experiment with techniques and approaches she had learned in class. Having a practical component to her teaching meant that she was able to take pedagogical theories learned in Methods beyond the realm of the theoretical and see which ones worked for her personality and her teaching style. The practicum appeared to increase Doris and Rebecca's confidence as teachers - for Doris, it gave her practical experience, and for Rebecca, it gave her the independence of working in a context where she had to design and implement her own lesson plans.

The practicum also allowed my participants to personalize the concepts they had been learning in class. Although Doris and Rebecca were the only ones who explicitly stated that they had learned how to put the ory into practice over the course of the first year, Lisa and Jesús showed some evidence of also combining these two elements. By 
and large, my participants did not begin to actually discuss themselves as teachers-their roles, the ir preferences, the ir style - until they had taken the practicum. When they did discuss themselves as teachers, the terms and concepts they used came directly from curricular content. This suggests that my participants needed a practical component in order to fully synthesize pedagogical (and, to some extent, linguistic) theory with their own teaching practice. Not only did the y need a practical component, they needed a practical component which incorporated hands-on teaching, reflection, and structured lesson planning. This was equally true for participants who had had teaching experience prior to entering the program and partic ipants who had not. My participants needed a combination of soc ially-situated and reflective learning in order to fully synthesize program content and de velop as teachers.

My participants' experience with the practicum highlights a contrast that appeared between participants' attitudes toward coursework focused on teaching practice versus coursework focused on linguistic disciplines and research. This the me, the division between theory and practice, emerged to some degree in all of my participant narratives. My participants appeared to group any course content not explic itly related to teaching together under the label of "the ory." I observed course content from SLA, Understanding the International Experie nce, and later, the Methods sequence, all be ing discussed as "theory." My participants did not appear to distinguish between theory and research, either, sometimes using the terms interchangeably. 
When my participants discussed "theory/research," they largely referred to it as confusing, unhe lpful, or uninteresting. However, they also mentioned actively integrating pedagogical theory from Methods into their beliefs and approaches to teaching. Some participants, by the end of the year, also appeared to be taking away some concepts from classes other than Methods; however, they continued not to explicitly relate these concepts to the ir beliefs about teaching. Despite this, there is evidence in the language they used when discussing their beliefs that they were influenced by these concepts. The theory/practice divide appeared to be largely a mental construct put in place by my participants. Any course content that they regarded as unhelpful, uninteresting, or difficult remained in the realm of theory, while theoretical concepts that they found useful or interesting became integrated into practice.

This leads to another theme that emerged in participant narratives: a dis like of theory and research. Three of my participants entered the program with no background in social sciences and little familiarity with the field of linguistics. In fact, three of my participants expressed a lack of interest in, and in some cases, a dislike of, doing coursework related to applied linguistics and research. This dislike of the subject area may have compounded their mental division between theory and practice. They resisted talking about theory as something positive even after showing evidence of integrating it into the ir practice.

Another factor that may have contributed to my participants' view of program content was the factor of stress. My participants experienced significant stress during 
their first term; this may have colored the ir experience during subsequent terms. It also may have re-enforced the ir preexisting bias toward theory. The required courses for the first term focus mainly on introducing students to research and coursework in applied linguistics. Because these were areas in which three of my participants had little previous knowledge, they felt a good deal of stress. They reported having a "just do it and get it done" (Rebecca, Interview 2) approach to coursework. They were focused less on understanding and integrating the concepts presented in class and more on finishing their coursework within the required deadlines. The combination of stress and a preexisting lack of interest in the majority of course content may have contributed to the divide between theory and practice in my participants' minds. The pattern they adopted in the first term of seeing linguistics- and research-related coursework as unrelated to practice carried over into subsequent terms.

My participants did begin to show some evidence of integrating linguistic- and research-related aspects of coursework into the ir practice, even when they themselves did not comment on it. However, this did not happen until after they had taken the practicum. This is especially evident in Rebecca's and Doris's narratives. Having field experience provided the necessary impetus for relating practice to theory. In both cases, these two participants explicitly stated that using concepts from their classes in their practice helped see the significance of theory. In Lisa's narrative, there was also evidence that her beliefs changed as a result of practical experience and theoretical know ledge. The reflective element in practicum curriculum appeared to help my participants see the connection 
between theory and practice by encouraging them to examine not only what they did in class, but how and why they did it.

Another factor that contributed to partic ipants' deve lopment was interaction with fellow students. Although none of my participants explicitly linked this to the development of their beliefs, they did credit the experience of having a small, closely-knit cohort with reducing stress and building valuable interpersonal relations hips. They also reported finding group work at the graduate level helpful for processing new information; the mixture of different perspectives illuminated course content and allowed for deeper understanding. The social experience of having a small, close-knit cohort contributed to their learning as teachers and as students.

Interactions with faculty were also helpful, particularly in providing students with a sense of empowerment. My participants appreciated feeling safe enough in the program to talk to professors when they were having trouble with assignments or disagreed with the parameters set forth by a specific assignment. Each of my participants reported that they found the faculty supportive and accommodating, which reduced the level of their stress.

When speaking about the ir experience in the program, my participants discussed themselves both as students and as teachers. I found it difficult to separate their discussion of the ir teacher identity from their discussion of their student identity. Various elements of program curriculum appeared to contribute to the ir de velopment as students and as teachers. They credited the practicum and Methods sequence with the majority of 
their development as teachers, but I saw evidence that concepts from other classes also became a part of their evolved system of teaching beliefs. Likewise, my participants credited group interactions, interactions with the faculty, and the graduate research sequence with aiding the ir development as graduate students. However, I saw evidence that my participants also gained valuable study and organization skills from courses like the practicum. The ir beliefs about teaching and learning appeared to be influenced both by their experience as teachers and their experience as students. They may have needed the combined experience of being a student and a teacher-in-training in order to fully develop and refine the ir beliefs.

\section{SUMMARY}

Course content and practical experie nce appeared to contribute most to the evolution of my participants' beliefs, though other factors also came into play in their successful navigation of their first year in the program. Throughout the course of the year, many of my participants displayed a resistance to or even dislike of the concept of "theory." However, an examination of the ir narratives suggests that they began to incorporate theories from course content into their beliefs about teaching by the end of the year. This inc orporation of course content into practice appeared to happen largely as a result of socially-situated, hands-on experience and reflection on that experience. My participants linked their evolved beliefs in the final interview mostly to their experience in the practicum, despite evidence that they were also incorporating theories and concepts from other courses. 
This chapter presented the narratives of my four partic ipants' experiences in the ir first year of the program. It also disc ussed how these narratives did or did not answer my research questions. It also discussed some themes that emerged in the results-most significantly, the the me of theory versus practice. I will discuss the implications of my research in the following chapter. 


\section{CONCLUSION AND IMPLICATIONS}

\section{INTRODUCTION}

In the following chapter, I summarize my findings, then discuss the implications of these findings. Next, I discuss the limitations of my study and areas for further research. I conclude with a short reflection on my own experience in the program and how it has been affected by conducting this study.

\section{SUMMARY OF FINDINGS}

I found that my participants' be liefs did change, or evolve, as a result of program curriculum. My participants expressed much more nuanced and clearly-defined beliefs at the end of the year as compared to their beliefs at the start of the year. They also gained greater awareness of teacher-student roles and of their own identities as teachers. They attributed the majority of change to hands-on teaching experience in the practicum, but they als o acknow ledged the Methods sequence as helpful to the ir development as teachers. There was implic it evidence in the language they used that terms and concepts from other core classes also had an influence on the development of their beliefs.

By the end of the year, my participants had begun to synthesize pedagogical theory with practice. However, they continued to view the research-related element of program curriculum — and, to some extent, the linguis tic component of curriculum — as unrelated to teaching. Furthermore, three of my participants expressed disinterest in 
research and a desire for more teaching opportunities in the program. They felt that there was too much emphasis on theory and research in program curriculum and not enough on teaching practice.

My findings revealed the existence of a series of perceptual mis matches (Kumaravadivelu, 1991) between how the program views its curriculum and how students want the curriculum to be. The mismatches I saw occurring in my results were what Kumaravadivelu would designate as "pedagogic mismatch[es]" (p. 90), where the students' and the instructor's - or, in this case, the program's - perceptions of the purpose of a lesson or curriculum are not in agreement. The program curriculum is designed to integrate coursework in linguistic disciplines, research, and pedagogy with the purpose of preparing students for various careers in the TESOL field, not just teaching but administration, curriculum or assessment design, etc. The goal of my participants, however, was to become better classroom teachers. Each participant stated this at the beginning of the year and continued to restate this goal throughout the course of the study.

My participants repeatedly expressed the sentiment that program curriculum focused too much on "the ory" or research and not enough on practice teaching. They showed a tendency to group together all course content that was not interesting to them or not specifically related to teaching practice under the category of "the ory." They showed a resistance to integrating "theory" into their practice, and some dismissed the research component of program curric ulum altogether. 
By the end of the third term, my participants did begin to integrate concepts that they viewed as "theoretical" into the ir practice. The majority of concepts that they integrated were from pedagogical the ories that they had learned in Methods classes; however, they also inte grated some amount of linguistic knowledge as well. Figure 2 (below) shows the difference between the program view of curriculum and the students' view of curriculum.

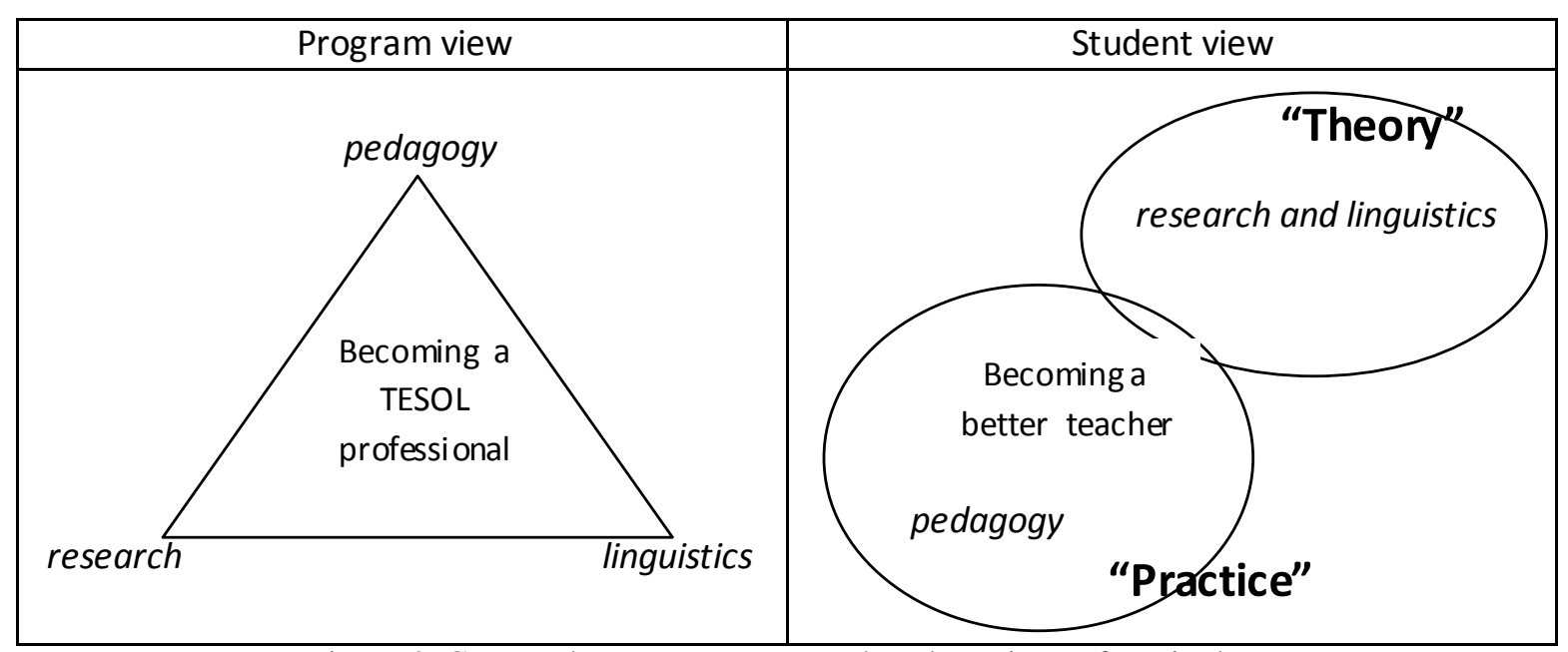

Figure 2: Contrast between program and student views of curriculum

As can be seen above, my partic ipants grouped research and linguistics together as curricular elements that were not relevant to teaching practice. A slight overlap can be seen where they began to integrate aspects of these two areas into the ir teaching, but by and large, they consistently saw practice as the main contributor to learning how to teach. Conversely, the program view does not divide coursework into "theory" and "practice", but integrates theory and practice into a three-stranded curriculum where each strand influences and interacts with the others. 
Another major pedagogic mismatch shown in this figure is the difference between program and student goals. My participants consistently desired curriculum to contribute to the goal of becoming a better ESOL teacher. The program views its curriculum as contributing to the goal of becoming a professional in the TESOL field, which includes but is not limited to classroom teaching. It appears that students not only failed to see linguistics and research as integral parts of program curriculum, but the ir goals for the program were also limited to the pedagogical element of the curriculum.

A final mismatch lies in my participants' perception of Graduate School as a whole. Two of my participants viewed the program as a way to obtain a degree and, subsequently, a job. They expressed little interest in expanding the ir know ledge in the field of applied linguistics. Doris was the only participant who reported having an interest in gaining more knowledge about the field. Though Rebecca and Lisa did encounter and pursue concepts they found interesting, they did not enter the program with the intention of expanding their knowledge. My participants appeared to view Graduate School—or at least this program — as a means to a degree, not a means to developing a professional body of knowledge in a certain field. This is different from the program view, which conceives of the program as a way for students to become know ledgeable in the field of applied linguistics and TESOL.

My participants did not initially perceive knowledge of research and linguistics as contributing to their skill as teachers. Although they began to see the benefit of this knowledge later in the year, they still saw hands-on practice as the most important 
contributor to their development. Some of my participants did acknowledge that the nonpedagogical components of curriculum were helpful and interesting, but they cons istently expressed the feeling that there was too much emphasis on research and linguistics and not enough on teaching. All four of my participants expressed frustration with the limited amount of practice.

Because my participants were so focused on the practical element of teaching, it is not surpris ing that the Community Practicum played a large part in each of their narratives. The Community Practicum is the only course that offers teaching experience and credit hours, so it might seem counterintuitive for an MA TESOL student not to chose to take it. However, it is listed under the Language Education elective category in degree requirements. Students need only four credits, or one course, from this category in order to graduate. Many MA TESOL students choose to take a different course from this category based on the ir area of interest. It appears that my four participants were primarily interested in hands-on teaching to the extent that they were willing to take only the practicum or to take extra credits in this category.

Other opportunities for teaching community ESL exist outside of the university, and many students in the past have taken advantage of these. However, the practicum is different from other community ESL contexts that my participants would have encountered. The two most significant differences are the requirement to write and reflect upon plans for every lesson and the weekly check-ins with a supervising professor and fellow teachers-in-training. The unique nature of the practicum-not only its practical 
element but also its focus on reflective practice and organization-appeared to contribute dramatically to my participants' growth as teachers and to their awareness of the role of theory in practice. The practicum enabled my participants to apply pedagogical theory firsthand. It did not overtly appear to help them integrate research and linguis tic theory into their practice; however, those of my participants who did begin to see research and linguistics as important to teaching did so after or during their time in the practicum. There may, therefore, have been a correlation between the practicum and my participants' ability to integrate the ory or see theory as useful and valuable.

This leads to another finding: a mis match between what my participants believed about the curriculum and what the ir vocabulary suggested. My participants consistently reported finding the ory less useful than practical experience; some reported integrating very little - if any - theory into the ir practice by the end of the year. However, all four participants in their final interviews discussed teaching using a vocabulary rich with concepts and terms from various classes whose content they had previous ly labeled as "theoretical." This suggests that, a lthough they believed theory to be less useful than hands-on practice, they did benefit from the theoretical aspects of coursework. My participants themselves were largely unaware of how the ory influenced their beliefs.

My findings supported the findings of several earlier studies. My participants entered the program with predetermined beliefs about teaching, which was also shown in Hollingsworth, 1989; Kagan, 1992; Lasley, 1980; Pajares, 1991; and Weinste in, 1990. Many of my subjects had taught before, but those who had not still reported strong beliefs 
about what made a good teacher. Doris's results in particular were in keeping with Pajares's (1991) assertion that PSTs form their opinions on teaching as students; she entered the program with a background in academia and reported that her experiences as a student had shaped her beliefs about teaching.

One major finding was the mental division that my participants demonstrated between the concepts of theory and practice. My participants, like those in previous studies (Ethell \& McMeniman, 2000; McCray, 2006), appeared to value practical experience over theoretical coursework in their development as teachers. They had little conception of theory and practice as being intertwined, instead viewing them as completely separate aspects of program curriculum. Like many of the students in previous studies, they credited hands-on teaching practice with the majority of their development as teachers. They appeared to enter the program not only with preestablished beliefs about teaching and learning, but also with beliefs about how teachers learned best. This was a finding that I did not anticipate but which echoes the results of previous studies.

My findings had a number of implications for the program, which I will discuss below.

\section{IMPLICATIONS AND SUGGESTIONS}

One major implication is the pedagogical mis match between program design and goals and the goals and perceptions of my participants. This indicates that students may 
enter the program without a thorough understanding of its content. By the end of the year, my participants appeared to gain better understanding of how theory and practice could be interrelated, but they continued to value practical experience over know ledge of linguistics and research. Their resistance to research and linguistics meant that they may not have synthesized the different strands of program curriculum as fully as had been intended.

A more unified view of program curriculum and its goals would be helpful for students to know from the beginning what program curriculum encompasses. Currently, there are several different descriptions of the program curriculum that are being used in information sessions for new students. For example, the materials used in the student orientation describe the three strands of program curriculum as "Research, Practice, and Service" (Graduate Orientation Powerpoint, 2011). However, the department Chair described the three strands as I have them listed in this study: research, linguistic knowledge, and peda gogy. One single document that clearly outlines program goals, core curriculum objectives, and the way that each of the three strands of curriculum complement each other is vital for students to form a clear understanding of the curriculum.

An approach that other programs tried (Fleming, et al., 2011; Peter, et al., 2012) for making the connections between theory and practice more transparent was providing students with more examples of theory in practice. Students observed seasoned instructors, then held conferences with these instructors in order to dissect the ir lessons 
and find the theories and approaches behind their techniques. A similar activity could prove helpful to students in this program. Some students already get some exposure to seasoned instructors through the observation assignments for Methods, but increased communication with the instructors could be beneficial. An assignment where students had to interview an instructor that they had observed, for example, might expose students to more examples of how theory came into play in practice.

Because my participants reported that they were able to make connections between theory and practice by reflecting on their own lessons, it could also be helpful for students to read lesson plans and reflections written by professional TESOL instructors. Seeing the connections that professionals made between theory and practice could provide students with insight into how the two can be interrelated.

My participants also reported that group discussion with fellow students helped them synthesize material covered in classes. They reported appreciating the group projects in the Methods sequence and the opportunities for group discussion in the class sessions for the practicum. More opportunity for discussion in small groups could help students process course content, especially in courses that are not specifically related to pedagogy. Many students in the past have found study groups helpful, but few courses offer teacher or TA-run study sessions. Small study sessions for the Graduate Research sequence could be particularly helpful for students who were having trouble synthesizing the material, especially given that these courses only meet once a week. 
The largest issue with my results, however, was not that my participants did not understand program curriculum, but that they did not agree with it. My participants had a mismatch not only of perception but als o of goals and objectives. While the program's goal was to prepare students for more than just classroom teaching, my partic ipants were interested primarily in becoming teachers. All of my partic ipants expressed a desire for less linguistic and research-related coursework and more practical experience. Several of my participants—notably, Jesús and Lisa - either did not expect or were not prepared for the linguistic element of the program.

The program could take two possible approaches to this problem. The first would be requiring more of a background in linguistics from pros pective students, thus ensuring that program applicants had an interest in linguistics and were also familiar with the discipline. The other approach would be to incorporate more teaching practice into the curriculum, either by offering more options for practical experience, adding more teaching-re lated assignments into required courses, or a combination of both.

If the program did require a more extens ive background in linguistics (for example, a Bachelor's degree) from its applicants, prior knowledge of the discipline might reduce stress, make coursework less challenging, and ensure that program and student goals were in agreement. However, many students (like Lisa and Rebecca) are from the area and choose this particular program because of its proximity. They do not specifically seek it out because of its linguistic element, nor do they come from a background in linguistics. To require students to have a background in linguistics would 
greatly limit the number of people who applied and make it impossible for some aspiring ESL teachers in the area to obtain a degree without moving to another city or state. Requiring a previous degree in linguistics would therefore not be realistic considering the demographics of program applicants.

However, some know le dge of linguistics is necessary. I would recommend that the program continue to require Introduction to Linguistics as a prerequisite. I would also recommend that the program be more stringent about what equivalents to the Introduction to Linguistics requirement it accepts. Lisa's narrative is an example of a case where her supposed prerequisite was not actually a linguistics course. In cases like this, the respons ibility to ensure a background in linguistics also lies with the student. However, the program could include a list of skills needed for core classes (e.g. familiarity with the International Phonetic Alphabet, experience analyzing learner language) in the orientation materials. This would give applicants a clear view of what they needed to know before registering for courses and help them determine whether or not they needed to take Introduction to Linguistics. This would ensure that students did not enter the program with no prior knowledge of linguistics, or that, if they did, they would take Introduction to Linguistics before taking any other classes.

I would also recommend that the program require students to take Structure of Englis h concurrently with Introduction to Linguistics. This would ensure that all students enter the program with the appropriate background knowledge and with a better idea of what to expect in upcoming terms. This would help mitigate the problem of students 
entering the progra $\mathrm{m}$ with no preparation. It would also allow students to give the program a probationary period in which they could determine whether its goals and content were in keeping with their own goals and interests.

Because my participants were primarily interested in teaching practice, I would also recommend that the program incorporate more explicit connections to teaching into required coursework. The graduate research sequence and Second Language Acquisition were the courses that my participants expressed the most discontent with because they saw little to no connection in course content to their goal of teaching. The curric ulum for SLA already requires students to analyze learner language. A good follow-up assignment for the language analys is assignments would be a write-up of what kind of techniques and approaches could be used to combat and repair learner errors. This would make the connection between analyzing learner language and teaching more transparent.

In the graduate research sequence, students are required to read and analyze scholarly artic les. The analys is focuses large ly on structure and technique s of writing. Incorporating more articles written by ESL teachers might help students see the connection between teaching and conducting research. It might also help to have students come up with a proposal for a hypothetical study whose results would address a teaching concern. Although students write research questions and a literature review during the second class in the research sequence, having them practice writing a proposal related to in-classroom research during Introduction to Graduate Study might give them ins ight into how research could be used as a teaching aid. 
I would also suggest that students be made more aware of other opportunities for teaching and tutoring in the community. Many students do not become aware of the teaching opportunities at the local hospital and community colleges until their second year in the program. For students who want to start teaching as soon as possible, this can be frustrating. Making students more aware of outside opportunities would enable those who specifically want to teach, like my participants, to pursue their interests early in the program. It might also motivate students to take advantage of these opportunities if they had the option of earning credit. A special topics course that required students to de sign and implement lessons at the nearby hospital or community college would be a good way to provide students with teaching experie nce and school credit. Because my results suggested that my participants needed a practical component in order to synthesize program curriculum, enabling them to teach earlier in the year might he lp them make the connection between theory and practice earlier in the year.

I have suggested various approaches that the program could take both in bridging the gap in students' minds between practice and theory and in address ing students' interest in teaching practice. There were also several existing elements of program curriculum that my participants appeared to find effective in their development as teachers.

The most significant contributor to students' making connections between theory and practice was the opportunity to teach in a safe, experiment-friendly environment. The practicum allowed my participants to develop and implement the ir ow $\mathrm{n}$ curriculum and to 
draw on concepts from class. It also exposed them to much-desired teaching practice. Because the practicum proved to be such a valuable experience for my participants, I would suggest that the program promote the practicum more extensively and ensure that students are aware of it. Currently, the instructor who teaches the practicum comes into Methods classrooms to recruit teachers for each term. It would also be useful for the Methods syllabus and program orientation materials to make mention of the practicum as well.

I would not necessarily recommend that the practicum be a required course, since there are only a limited number of teaching sites and it could be difficult to accommodate the needs of all members of the MA TESOL cohort. However, the way in which the practicum is listed in the course list is currently problematic. It is an elective class in the Language Education category, which contains six other elective classes. Out of these seven classes, students must choose only one to fulfill the ir Language Education requirement. Many students choose not to take the practicum because they prefer to take another course in the Language Education category. Dividing this category into two sections or requiring more elective credits from this category would give more students the opportunity to take the practicum.

The reflective element of coursework was also helpful for my participants. This is a part of program curriculum that appears to be functioning well and doing what it was designed to do: making students more aware of their own teaching practice and of the 
various elements that go into becoming a good teachers. I would recommend that the program retain its reflective component.

My findings also implied that the program's goal for students is more complex than students' goals. I addressed this somewhat above in the discussion of having a more unified view of program objectives within the department. Having program documents such as a handbook, orientation materials, and a more detailed program description on the website would also help students become cognizant of program goals before they begin taking classes. It would als o be helpful for orientation materials to contain a list of possible professions that people with an MA TESOL degree can pursue. Although this is sometimes addressed in one-on-one orientations (K. Walters, personal correspondence, January 27,2013 ), the information is currently not available in a written format accessible to students. My participants appeared to enter the program with no awareness of profess ional options in the TESOL field other than teaching. Making prospective students aware of the different directions they could take with their degree would help illuminate the program goals and the different elements of the curriculum. This would be a valuable resource even for the students exclusively interested in teaching, as it would help inform them as to why the curriculum is structure dhe way it is.

Another implication of my findings was that stress had an adverse effect on students' experie nce of the program. Many of my participants reported feeling overwhelmed or lacking motivation because of their level of stress. Requiring students to take Introduction to Linguistics and Structure of English before any other classes would 
address this problem both by preparing students for coursework in linguistic disciplines and, for stude nts who had been out of school for several years, by easing them back into the world of university-level education. The presence of study sessions for classes like Second Language Acquisition and the graduate research sequence would also help students deal with stress by giving them more exposure to the material and more time to practice and process what they had learned in class. However, implementing study sessions for these courses would require additional funding.

\section{LIMITATIONS AND AREAS FOR FURTHER RESEARCH}

In the course of analyzing my data, I found several limitations to my results. Because I designed my study as a case study, I cannot be sure that the experiences of my participants can be generalized to the rest of the MA TESOL cohort or to students in other MA TESOL programs. My participant group was also very homogeneous, which limited the perspectives present in my results. Three of my participants had little to no interest in research or applied linguistics. Doris was interested in applied linguistics but remained, like my other participants, more invested in getting hands-on teaching experience. My participants' overwhelming focus on teaching-related coursework and their lack of interest in research limits the scope of my results. It is impossible for me to determine whether my participant group represents a trend within the larger MA TESOL cohort or whether the focus on teaching practice is unique to my participants.

Another limitation also related to my study design is the time in which it occurred. I can only describe the experience of my participants during their first year in 
the program. It is therefore impossible to determine whether their integration of theory and practice improved during the course of their second year. I also cannot tell whether their beliefs continued to evolve during the rest of the program.

My limitations highlight several areas for further research. Further research is needed on how to repair the practice/theory divide in PST training. Although previous studies, this one included, have provided evidence that such a divide does exist, there has been little research done on ways that PST training programs can successfully integrate theory and practice. Teacher-based action research that focused on designing and implementing approaches to integrating theory and practice would be a useful addition to the field.

Another area for future study would be the difference between beliefs in PSTs with teaching experience and those without. Three of my participants had experience teaching before they entered the program, while one did not. It would be interesting to determine in a future study whether this had any bearing on my results. It would also be interesting to see a study with a larger sample size and an equal number of students who had taught and students who had not taught.

My results also raised the question of the effect of stress on students' ability to make connections between various areas of coursework. A study that focused not only on the practice/the ory divide but also on whether this divide is influenced by stress would be useful and informative. 
A longer-term study would also be beneficial. My study did not follow my participants beyond the ir first year, but a study that followed students throughout the entire course of a graduate program or which interviewed students several years after graduation might yield interesting results about the inte gration of theory in practice over time.

\section{CONCLUSION}

Past studies have shown that PSTs enter teacher education programs with preexisting beliefs about teaching and learning. The aim of this study was to determine what effect the first year of a specific program had on these beliefs. I found evidence that PST beliefs evolved and that PST knowledge deepened as a result of program curriculum. However, I also found that my participants had difficulty integrating the research and linguistic strands of program curriculum into their teaching practice. Although my participants had begun to do this by the end of the first year, their goals were still not in keeping with program goals and they did not demonstrate a clear understanding of the reasoning behind program curriculum. Although the curriculum was largely effective in inciting change in my participants, my participants' perception of the curriculum remained different from the program's perception.

When I began this study, I was as confused as my participants about how the program curriculum was designed. Despite having completed my first year, I had no additional insight into the reasoning behind various aspects of the curriculum. In many ways, my experience paralleled that of my partic ipants. I completed my first year feeling 
much more confident and knowledgeable as a teacher and student, but I still was not sure why I had to take certain classes or how they would help me with teaching. It was only when I started talking to instructors and researching the program that I discovered the underlying purpose behind program design and the links between various aspects of the curriculum. For me, transparency came through research. However, most students in the program do not have the luxury of - or the reason for-conducting research on program curriculum. My hope for future students would be a curric ulum that addresses students' interests and makes the links between research, linguistics, and pedagogy clear. I believe that when these links are made obvious, students will be more able to get the most out of the program from the beginning and come closer to fulfilling the ir ultimate pote ntial as future educators and TESOL professionals. 


\section{REFERENCES}

Bunting, C. E. (1984). Dimensionality of teacher education beliefs: An exploratory study. The Journal of Experimental Education, 52, 195-198.

Bontempo, B. T. and Digman, S. (1985). Entry level profile: Student attitudes toward the teaching profession. Paper presented at the annual meeting of the American Education Research Association, Chicago.

Clandinin, D. J. and Connelly, F. M. (1996). Teachers' professional know ledge landscapes: Teacher stories. Stories of teachers. School stories. Stories of schools. Educational Researcher, 25, 24-30.

East, D. K. (2011). Examining PSTs cultural beliefs and assumptions, literacy models, ideologies and identities. (Doctoral dissertation). Retrieved from ProQuest Dissertations and Theses Database. (3491467)

Ethell, R. G. and McMeniman, M. M. (2000). Unlocking the know ledge in action of an expert practitioner. Journal of Teacher Education, 51, 87-101. 
Fleming, D., Bagnou, F., and Fellus, O. (2011). ESL teacher-candidates' be liefs about language. Revue TESL du Canada, 29, 39-56.

Frusher, S. S. and Newton, T. (1987). Characteristics of students entering the teaching profession. Paper presented at the Oklahoma Educational Research Symposium.

Hollingsworth, S. (1989). Prior beliefs and change in learning to teach. American Educational Research Journal, 26, 160-189.

Jacobs, E. B. (1968). Attitude change in teacher education: An inquiry into the role of attitudes in changing teacher behavior. Journal of Teacher Education, 19, 410415.

Kagan, D. M. (1992). Professional growth among preservice and beginning teachers. Review of Educational Research, 62, 129-169.

Kumaravadivelu, B. (1991). Language learning tasks: Teacher intention and learner interpretation. ELT Journal 45, 98-107

Lasley, T. J. (1980). PST beliefs about teaching. Journal of Teacher Education, 31, $38-41$. 
Lin, L. (2000). On the developmental journey: An ethnographic study of teacher identity development of NESTs and NNESTs in a US MA TESOL program. (Doctoral dissertation). Retrieved from ProQuest Dissertations and Theses Database. (3482248)

Liston, D. P. and Zeichner, K. M. (1991). Teachers' know ledge, models of inquiry, and the social context of schooling. In D. P. Liston and K. M. Zeichner, Teacher education and the social conditions of schooling (pp. 60-88) New York, NY: Routledge.

McCray, L. N. (2006). Knowledge, beliefs, and practice: ESL teachers and SLA research. (Master's thesis). Portland State University, Portland, OR.

Moore, A. (2004). The reflexive turn - exploring private and professional selves. In A. Moore, Good teacher: Dominant discourses in teaching and teacher education (pp. 141-167). New York, NY: RoutledgeFalmer.

Nespor, J. (1987). The role of beliefs in the practice of teaching. Curriculum Studies, 19, 317-328. 
O'Brien, M. A. (2004). Personal images in second-language teacher development: Exploration of a reflective teaching tool. (Master's thesis). Retrieved from ProQuest Dissertations and Theses Database. (0-612-91426-7)

Osterling, J. P. and Webb, W. (2009). On becoming a bilingual teacher: A transformative process for preservice and novice teachers. Journal of Transformative Education, 7, 267-293.

Pajares, M. F. (1992). Teachers' beliefs and education research: Cleaning up a messy construct. Review of Educational Research, 62, 307-332.

Pappamihiel, E. (2007). Helping preservice content-area teachers relate to English language learners: An investigation of attitudes and beliefs. TESL Canada Journal, 24, 42-60.

Peter, L., Paul, M., and Frey, B. B. (2012). Preparing teachers for success with English language learners: Challenges and opportunities for university TESOL educators. The Teacher Educator, 47, 302-327.

Pray, L., and Marx, S. (2010). ESL teacher education abroad and at home: A cautionary tale. The Teacher Educator, 45, 216-229. 
Putnam, R. T. and Borko, H. (2000). What do new views of knowledge and thinking have to say about research on teacher learning? Educational Researcher, 29, 4-15.

Rymes, B. (2002). Language in development in the United States: Supervising adult ESOL PSTs in an immigrant community. TESOL Quarterly, 36, 431-452.

Urmston, A. W. and Pennington, M. C. (2008). The beliefs and practices of novice teachers in Hong Kong: Change and resistance to change in an Asian teaching context. In T. S. C. Farrell (Ed.), Novice Language Teachers: Insights and Perspectives for the First Year (pp. 89-103). Oakville, CT: Equinox Publishing.

Weinstein, C. S. (1989). Teacher education students' preconceptions of teaching. Journal of Teacher Education, 40, 53-60.

Winer, L. (1992). "Spinach to chocolate": Changing awareness and attitudes in ESL writing teachers. TESOL Quarterly, 26, 57-80. 


\section{APPENDIX A: SAMPLE INTERVIEW QUESTIONS}

First interview

1. Please tell me a little bit about your background. Do you have teaching experience? What was your undergraduate degree in?

2. What interested you about this program? Did you apply to other programs?

3. What interested you about the TESOL field? What do you hope to do with your degree?

4. What would your ideal teaching environment be? Would you rather work with children or adults? In a higher ed. or community setting? In the U.S. or abroad, etc?

5. What do you think is the most important skill a teacher can have? What constitutes a good teacher, in your opinion? Why do you think this? What experiences have you had that shaped your perception of what a good teacher is?

6. What do you think constitutes a good language student? Why do you think this? What experiences have you had that shaped your perception of what a good student is?

7. What are some of your hopes for this program? What are some of your fears?

Subsequent interviews

1. Which assignments from this term did you enjoy/find particularly relevant? Which assignments did you dis like? Why?

2. Are there any concepts that you found particularly interesting or helpful from your coursework? Are there any concepts you disliked or found irrele vant? Why?

3. How do you feel about the program? Why?

4. Have you observed any changes in your perception of what a teacher should be and do? Why or why not?

5. What are some of your hopes and fears for next term? 


\section{Final interview}

1. Looking back over this year, can you see any change in yourself as a teacher-intraining? If so, how have you changed? If not, why not?

2. What were some of your most significant experiences in the program this year?

3. How do you feel about your first year in the program?

4. Were there any readings and assignments that you partic ularly liked? Why did they appeal to you? What impact did they have on you?

5. Were there any readings and assignments that you found unhelpful or irrelevant? Why?

6. Were there any classes that you particularly liked or dis liked? Why?

7. What do you think is the most important skill a teacher can have? What constitutes a good teacher, in your opinion? Why do you think this? What experiences have you had this year that shaped your perception of what a good teacher is?

8. What do you think constitutes a good language student? Why do you think this? What experiences have you had this year that shaped your perception of what a good student is?

9. How do you feel about yourself as a teacher?

10. Is there anything else you would like to say about the program that you think would be helpful to future MA TESOL students? 


\section{APPENDIX B: PROGRAM REQUIREMENTS FOR MA TESOL}

\section{Prerequisites for all graduate level LING courses except LING 571}

LING 390: Introduction to Linguistics (or equivalent)

LING 492: Structure of English (The MA TESOL Grammar Prerequisite can also be met by earning a passing score on the grammar test taken during your first quarter as an MA student)

\section{Required Credits}

\begin{tabular}{|c|c|}
\hline \multicolumn{2}{|c|}{ Group I: Language Education/Applied Linguistics Theory ( 20 credits) } \\
\hline 16 required credits: & $\begin{array}{l}\text { LING 538: Second Language Acquisition } \\
\text { LING 571: Understanding the International Experience } \\
\text { LING 577: TESOL Methods I } \\
\text { LING 578: TESOL Methods II }\end{array}$ \\
\hline Choose 4 credits: & $\begin{array}{l}\text { LING 509: Practiaum } \\
\text { LING 539: Language Assessment } \\
\text { LING 565: Administration of ESL/EFL Programs } \\
\text { LING 570: Grammar for TESOL } \\
\text { LING 575: Curriculum Design and Materials Development } \\
\text { LING 576: Corpus Linguistics in Language Teaching } \\
\text { LING 510: Special Topics (on approval) }\end{array}$ \\
\hline
\end{tabular}

Group II: Foundations in Language and Linguistic Theory (8 credits)

\begin{tabular}{l|l}
\hline Linguistic Analysis: & LING 513: Linguistic Semantics \\
Choose 4 credits & LING 514: Linguistic Pragmatics \\
& LING 515: Linguistic Phonetics \\
& LING 516: Discourse Analysis \\
& LING 520: Historical-Comparative Linguistics \\
\hline $\begin{array}{l}\text { Linguistic Argumentation: } \\
\text { Choose } 4 \text { credits }\end{array}$ & LING 511: Syntax \\
\hline
\end{tabular}

Group III: Language and Society/Language and the Mind (8 credits)

Students may choose EITHER

- 8 credits from either category

- OR 4 credits from each category

\begin{tabular}{|l|l|}
\hline Language and Society & LING 532: Sociolinguistics \\
& LING 580: Bilingualism \\
& LING 581: World Englishes \\
& LING 582: Pidgins \& Creoles \\
\hline Language and the Mind & LING 533: Psycholinguistics \\
& LING 537: First Language Acquisition \\
& LING 545: Linguistics \& Cognitive Science
\end{tabular}


Group IV: Research Studies and Culminating Experience (12 credits)

\begin{tabular}{l|l} 
Required courses: & LING 559: Introduction to Graduate Study (2 credits)
\end{tabular}

LING 560: Research Design (2 credits)

LING 561: Research Methods (2 aredits)

Culminating Experience ( 6 credits) 


\section{APPENDIX C: PROGRAM REQUIREMENTS FOR METHODS TEACHING PORTFOLIO}

\begin{tabular}{|l|l|l|l|}
\hline \multicolumn{2}{|c|}{ PRACTICE COMPONENT } & $\begin{array}{c}\text { HOURS ACCRUED BEFORE } \\
\text { METHODS 1 OR OUTSIDE } \\
\text { ESL CONTEXT }\end{array}$ & NUMBER OF HOURS \\
\hline Teaching & at least 15 hours & & \\
\hline Observations & at least 15 hours & & \\
\hline Tutoring & at least 15 hours & & \\
\hline Other*) & TOTAL HOURS & max. 10 hours & at least 7o hours \\
\hline
\end{tabular}

*) Written Approval of Methods in structor Required

Table of Contents

_ Resume

__ Observation Report by Supervising Teacher

__ Observation Report by Peer from Methods 2

__ Reflective Statements

__ Statement from Methods 1

__ Statement from Methods 2

__ Final Reflective Statement

\section{TEACHING:}

_ Table Summary

_ Teaching Philosophy Statements

__ Statement from Methods 1

__ Statement from Methods 2

__ Final Teaching Philosophy

2 Full Lesson Plans from Methods 1 and 2

_ Lesson Plan Outlines for ALL practice teaching hours

8 Teaching Materials 


\section{OBSERVING:}

\section{Table Summary}

__Observation Reports for ALL Observations + Email Correspondence w/ Observed

Teachers (reports and correspondence need to be collated)

_Peer Observation from Methods 2 (done by you of a fellow student)

TUTORING:

_Table Summary

_-Tutoring Logs for ALL tutoring hours 